\title{
Directional Fluid Transport across Organ-Blood Barriers: Physiology and Cell Biology
}

\author{
Paulo S. Caceres, Ignacio Benedicto, Guillermo L. Lehmann, \\ and Enrique J. Rodriguez-Boulan
}

Margaret Dyson Vision Research Institute, Department of Ophthalmology, Weill Cornell Medical College, New York, New York 10065

Correspondence: boulan@med.cornell.edu

\begin{abstract}
Directional fluid flow is an essential process for embryo development as well as for organ and organism homeostasis. Here, we review the diverse structure of various organ-blood barriers, the driving forces, transporters, and polarity mechanisms that regulate fluid transport across them, focusing on kidney-, eye-, and brain-blood barriers. We end by discussing how cross talk between barrier epithelial and endothelial cells, perivascular cells, and basement membrane signaling contribute to generate and maintain organ-blood barriers.
\end{abstract}

\section{ORGAN-BLOOD BARRIERS}

$\mathrm{A}_{\mathrm{i}}^{\mathrm{c}}$ ccurate control of the composition of the internal medium is key to the survival of the organism. This depends on the directional absorptive and secretory activity of more than 150 different epithelia, mediated by $\sim 2000$ ion and nutrient transporters, channels, exchangers, and receptors, encoded by $\sim 5 \%$ of the human genome (Rodriguez-Boulan and Macara 2014). Parenchymal epithelial cells of the various body organs face on their luminal side a broad range of environments (e.g., gastrointestinal [GI] tract, urinary space, biliary space, retinal photoreceptors, cerebrospinal fluid), whereas on the basal side they face an internal medium of constant ionic composition constituted by the interstitial spaces and the blood circulation. The exchange of nutrients and waste products between organs and blood circulation is mediated by highly selective organ- blood barriers evolutionarily adapted to support organ function or/and organism homeostasis. Hence, the structure of these barriers and the driving forces that regulate fluid transport across them differ significantly (Table 1). Organ-blood barriers can display two layers (endothelial cells [ECs] and basement membrane) when ECs constitute the main component of the barrier (Fig. 1A,C,E), or three layers when parenchymal epithelial cells constitute a principal component of the barrier (Fig. $1 \mathrm{~B}, \mathrm{D}, \mathrm{F})$. Perivascular and local resident cells contribute in diverse ways to barrier assembly and maintenance. Some barriers (e.g., brain, inner retina, GI tract) are formed by monolayers of ECs sealed by tight junctions (TJs) that carry out blood-tissue exchange mostly via transcytosis across ECs. Other barriers (e.g., kidney glomerulus, kidney proximal tubule [KPT], choroid plexus $[\mathrm{CP}]$, endocrine glands, outer retina) display fenestrated ECs, which facilitate

Editor: Keith E. Mostov

Additional Perspectives on Cell Polarity available at www.cshperspectives.org

Copyright (C) 2017 Cold Spring Harbor Laboratory Press; all rights reserved; doi: 10.1101/cshperspect.a027847

Cite this article as Cold Spring Harb Perspect Biol 2017;9:a027847 
P.S. Caceres et al.
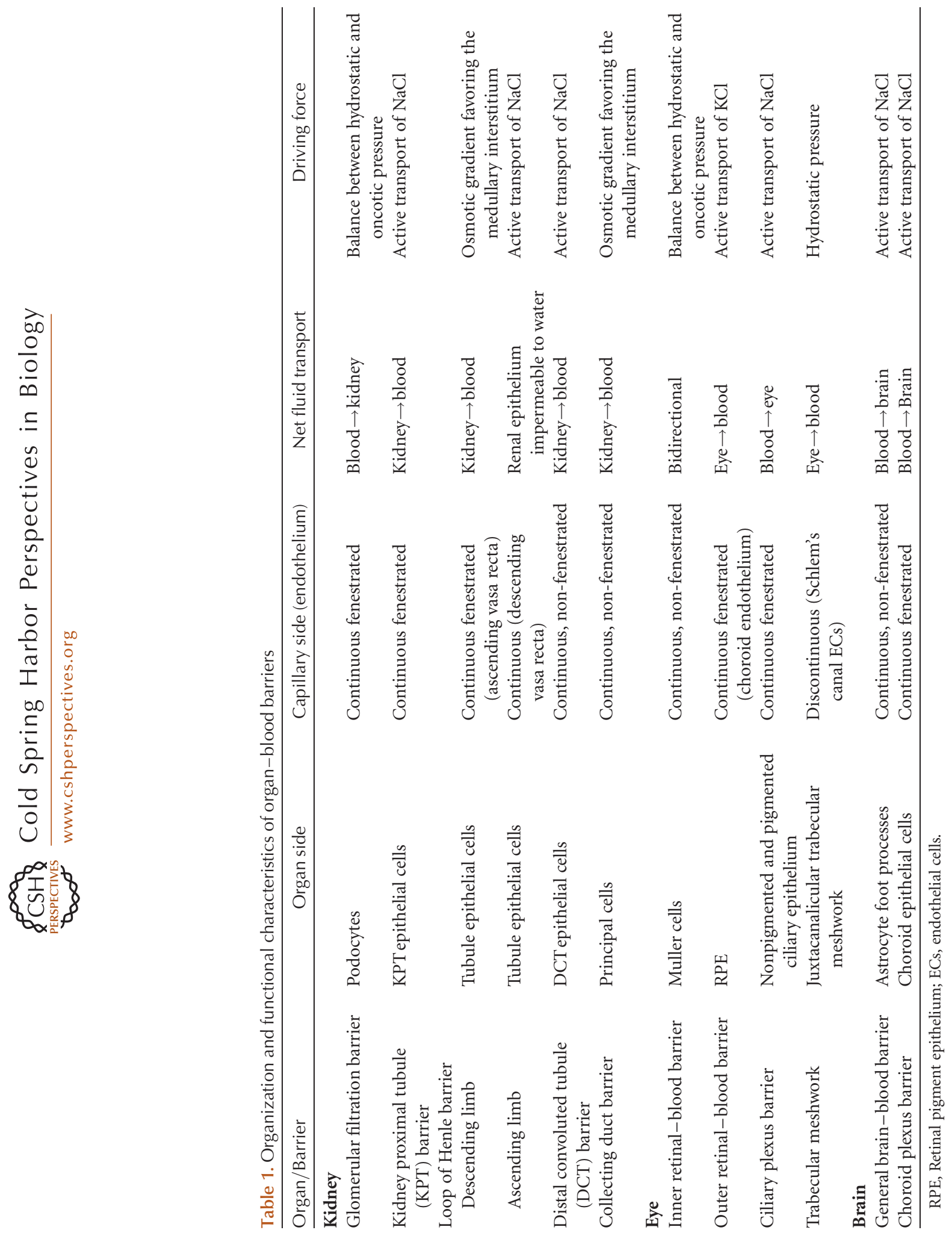
Kidney
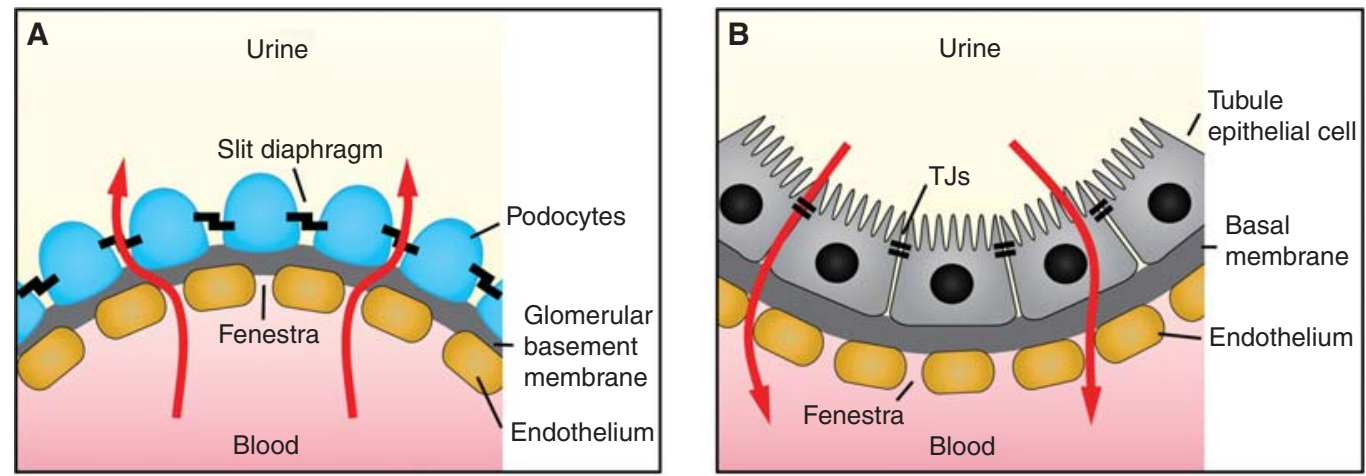

Central nervous system
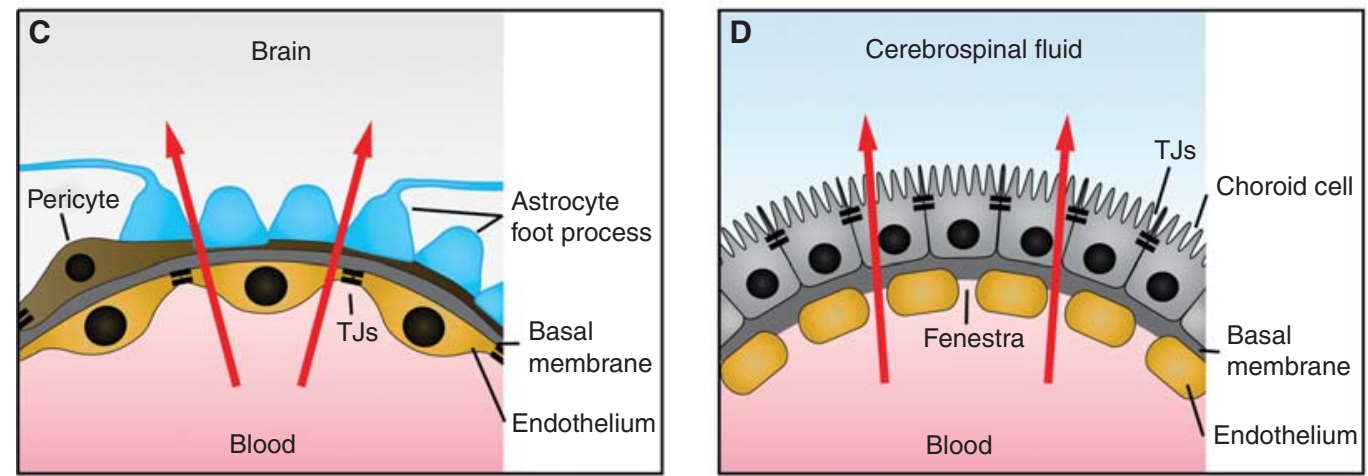

Eye
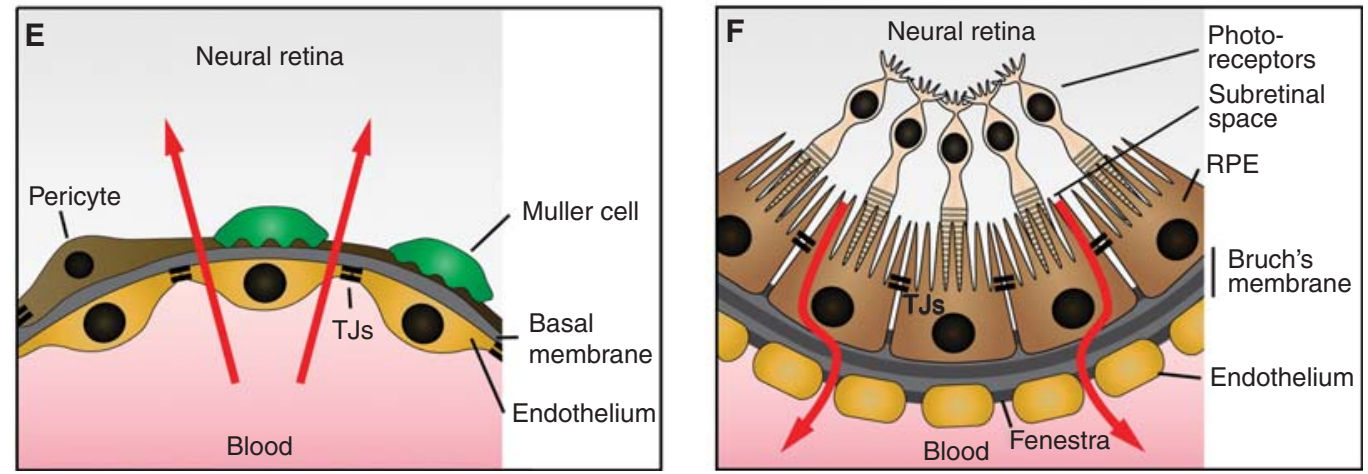

Figure 1. Organ-blood barriers in kidney, brain, and eye. Organ-blood barriers consist of a layer of parenchymal cells (top), a basement membrane (middle), and a layer of endothelial cells (bottom). (A) Kidney glomerular barrier, $(B)$ kidney proximal tubule barrier, $(C)$ brain-blood barrier, $(D)$ choroid plexus barrier, $(E)$ inner retina-blood barrier, and $(F)$ outer retina-blood barrier. Net fluid transport (represented by a red arrow) can follow a transcellular route $(C, D, E$, and $F)$ a paracellular route $(A)$ or both $(B)$. RPE, Retinal pigment epithelium; TJs, tight junctions.

the transport of proteins from the circulation into the tissue and vice versa. Here, we will review physiological and cell biological mechanisms that regulate directional fluid flow, an es- sential process for organ and body homeostasis, across kidney-, brain-, and eye-blood barriers. We will end by discussing emerging roles of ECs and stromal components in the regulation 
P.S. Caceres et al.

of structure and function of organ-blood barriers.

\section{DIRECTIONAL FLUID TRANSPORT ACROSS ORGAN-BLOOD BARRIERS}

Polarized fluid transport is an essential process for lumen formation during development (Lowery and Sive 2005; Bagnat et al. 2007; Khan et al. 2013; Kolotuev et al. 2013). Furthermore, various body organs transport large amounts of fluid for their own homeostasis (e.g., the eye, discussed below) or as a hallmark of their contribution to the homeostasis of the organism. For example, the kidneys filter $180 \mathrm{~L}$ of blood daily into the urinary space; most of this ultrafiltrate is recovered into the blood by the activity of the KPT (Weinstein 2013). The intestine also absorbs large amounts of fluid, whereas the CP secretes $500-600 \mathrm{ml}$ of cerebrospinal fluid into the brain ventricles.

Fluid transport was first observed in the gut (Reid 1902) and later confirmed by additional studies in intestine (Curran 1960; Parsons and Wingate 1961), gall bladder (Diamond 1962; Kaye et al. 1966), KPT (Windhager et al. 1959), retinal pigment epithelium (RPE) (Miller et al. 1982), and CP (de Rougemont et al. 1960). Although fluid absorption is known to occur mostly under isotonic conditions, various epithelia can transport fluid against an external osmotic gradient physiologically or under experimental conditions (Fig. 2A) (Parsons and Wingate 1961; Diamond 1962; Heisey et al. 1962). The Koefoed-Johnsen and Ussing model for active transport of $\mathrm{NaCl}$ across frog skin (Koefoed-Johnsen and Ussing 1958) framed the hypothesis of the coupled transepithelial $\mathrm{NaCl} /$ water transport (Curran and Solomon 1957). It was initially proposed that active water transport is an intrinsic property of certain epithelia accounted for by two membranes in series, one with low-solute permeability (highreflection coefficient) and another one with high-water and solute permeability (low-reflection coefficient) (Curran 1960; Durbin 1960). This hypothesis evolved into the three-compartment model, in which compartments A, B, and
$\mathrm{C}$ are separated by membranes with high- and low-reflection coefficients (Fig. 2B) (Curran and Macintosh 1962). According to this model, active solute accumulation in $\mathrm{B}$ drives water by osmosis from A to B, whereas hydrostatic pressure drives water from B to C. Correlative morphological/physiological studies established the identity of these compartments: A is the lumen, B the lateral intercellular space (LIS), and C the interstitial space (Williams 1963; Whitlock and Wheeler 1964; Tormey and Diamond 1967; Bentzel et al. 1969; Maunsbach and Boulpaep 1980). The standing osmotic gradient model (Fig. 2C) (Diamond and Bossert 1967) proposed that directional water transport was achieved by active pumping of $\mathrm{Na}^{+}$into a region of the LIS proximal to the TJ, which was assumed nonpermeable to water and ions, and fluid exit at the other end of the LIS, which was open and did not consider the contribution of a basement membrane. In contrast with the postulates of this model, subsequent experiments showed a homogeneous distribution of the $\mathrm{Na}^{+}, \mathrm{K}^{+}$-ATPase in LIS (Farquhar and Palade 1964; Stirling 1972; Kyte 1976), and LIS swelling in actively transporting epithelia (Williams 1963; Kaye et al. 1966; Tisher and Kokko 1974), which is compatible with TJ with moderate osmotic water permeability at the proximal end and a basement membrane with high (but not infinite) hydrostatic permeability at the distal end (Fig. 2D) (Weinstein and Stephenson 1981). Although the LIS concept is essential to explain water transport against an osmotic gradient (physiologically relevant to water transport by gall bladder and intestine), modeling studies suggest that LIS is not an absolute requirement for vectorial water transport (Schafer et al. 1977). Indeed, net water transport across KPT (and RPE, and CP) may be the result of a small $(2 \%-3 \%)$ favorable external osmotic gradient as observed across KPT epithelium (Andreoli and Schafer 1978; Andreoli et al. 1978), and interstitial oncotic pressure (Weinstein 1984). The osmotic model (Fig. 2E) (Spring 1998 ) relies on very high epithelial water permeability to transport water down a very small osmotic gradient in both directions, accounting for both absorption and secretion, depending 
Fluid Transport across Organ-Blood Barriers
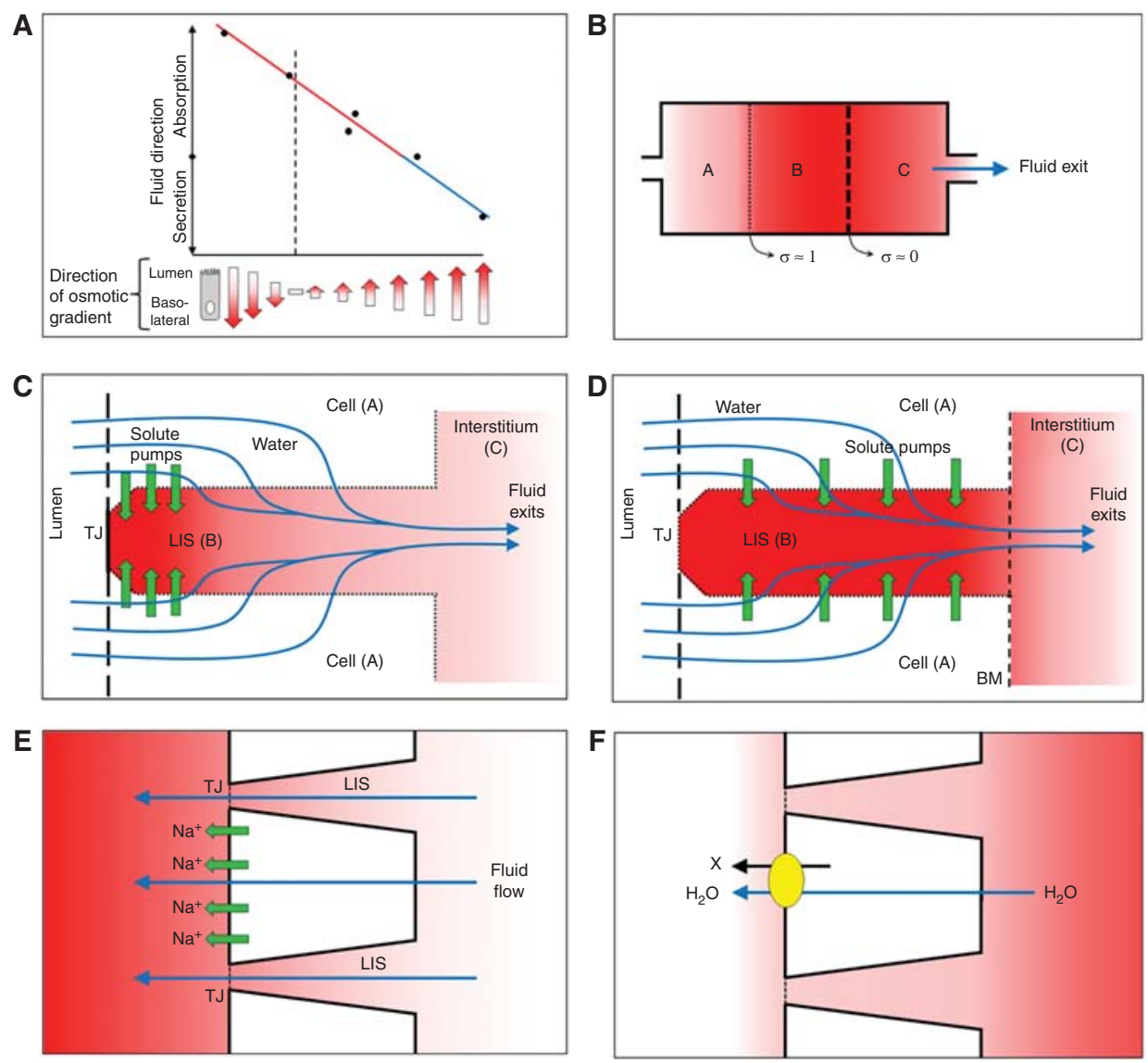

Figure 2. Directional fluid transport across epithelia. (A) Effect of osmotic gradients on the direction of fluid transport by gall bladder epithelium. (Panel is based on data in Diamond 1962.) Fluid flow was measured in gall bladder ( $y$ axis) to determine whether the epithelium was absorbing (red part of the trace) or secreting (blue part of the trace). The transepithelial osmotic gradient was manipulated to establish a driving force toward the lumen or the basolateral side ( $x$ axis). When the osmotic gradient was neutral (dashed line) isosmotic absorption was observed, and when the osmotic gradient reversed, the epithelium continued to absorb against the driving force until it eventually reversed the direction of the fluid toward secretion at higher osmotic gradients. $(B)$ Threecompartment model (Curran and Macintosh 1962). The three compartments $A, B$, and $C$ are separated by two membranes with a reflection coefficient $\sigma \approx 1$ (impermeable to solutes) and $\sigma \approx 0$ (permeable to solutes). Water moves from A to B by osmosis and from B to C because of hydrostatic pressure. $(C)$ Standing osmotic gradient model (Diamond and Bossert 1967). Active solute pumping into the blind end of the lateral intercellular space (LIS) drives water flow into the compartment and exit from it through the open end. The model assumes an impermeable blind end of the LIS. (D) Three-compartment model compatible with epitelial architecture (Weinstein and Stephenson 1981). Active solute pumping by the $\mathrm{Na}^{+}, \mathrm{K}^{+}$-ATPase into the intermediate compartment (LIS) generates the osmotic force for water absorption from the lumen through the intracelular space. The increase in hydrostatic pressure inside the LIS drives fluid exit through the basement membrane (BM) into the interstitium. The model assumes a higher reflection coefficient of the tight junctions (TJs) relative to the BM. (E) Osmotic model (Spring 1998). A small transepithelial osmotic gradient is sufficient to drive fluid flow (secretion in the illustration) thanks to the very high water permeability of some epithelia. This model applies to absorptive and secretory epithelia depending on the direction of the osmotic gradient. $(F)$ Water pump (Zeuthen and Stein 1994). Water is transported against an osmotic gradient coupled with one or more solutes $(\mathrm{X})$ using the favorable electrochemical gradient for the cotransported solutes. In all figures, the osmotic gradient is represented by the red shading, in which lighter indicates lower and darker represents higher osmolality. 
P.S. Caceres et al.
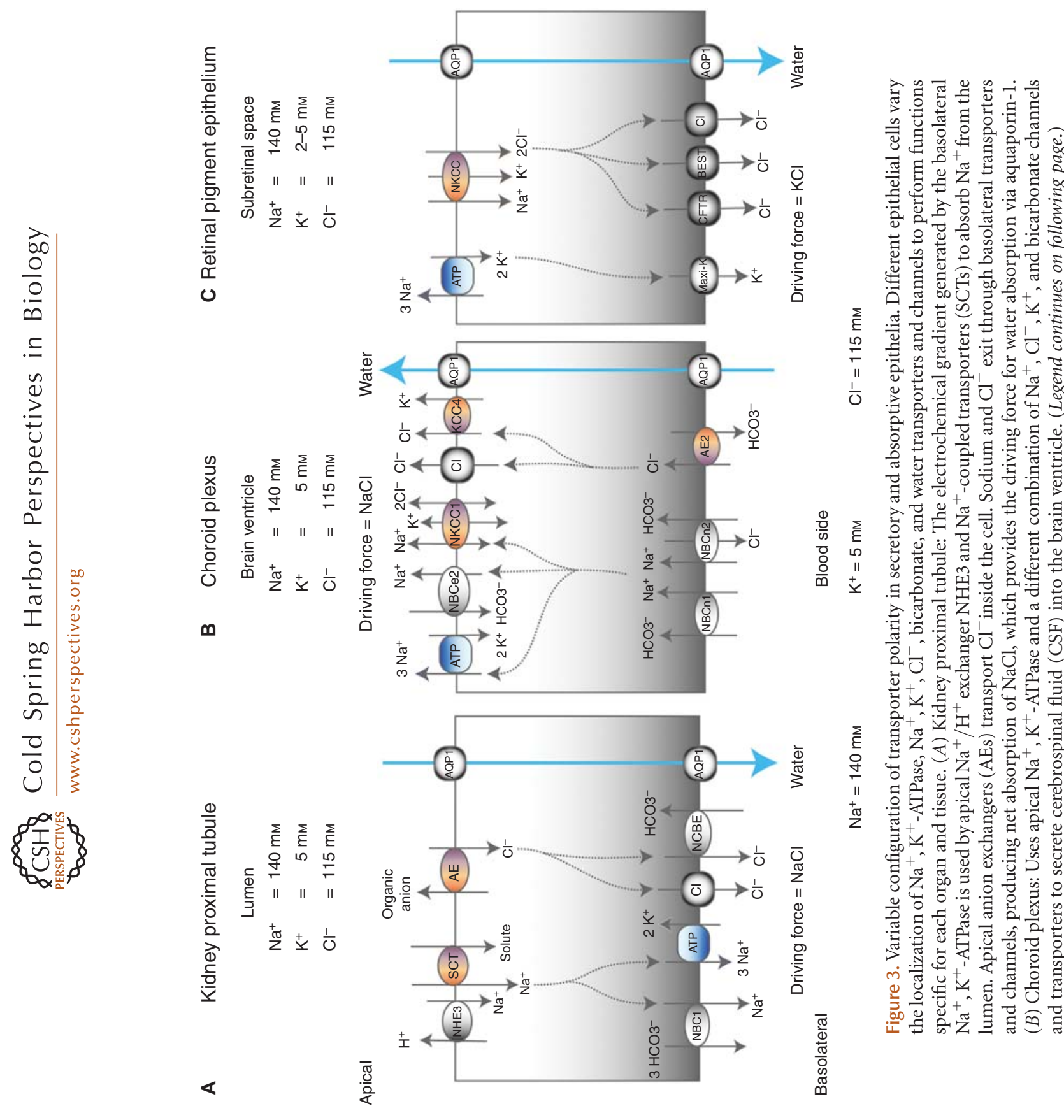

\section{象}

닐
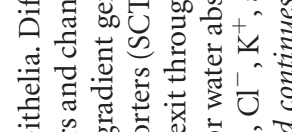

के

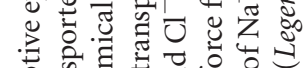

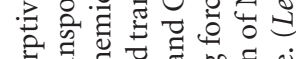

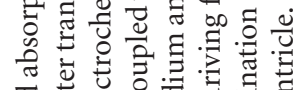

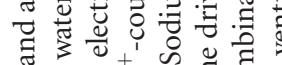

$\begin{array}{ll}\frac{0}{0} & \\ \frac{\delta}{0} & \varepsilon \\ \frac{\delta}{0} & 0 \\ \frac{0}{0} & 11 \\ \frac{0}{0} & +\end{array}$

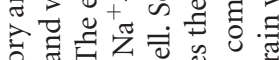

충

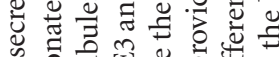

.

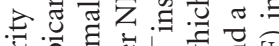

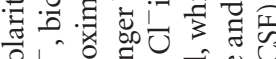

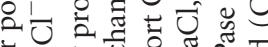

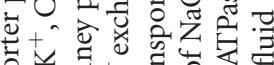

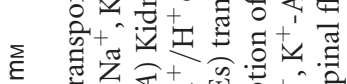

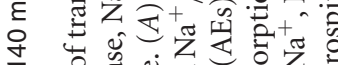

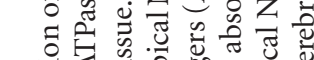

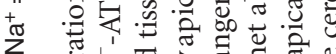

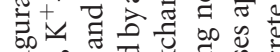

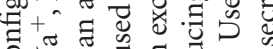

రี

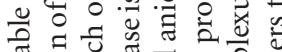

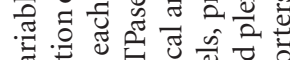

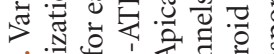

ल

응

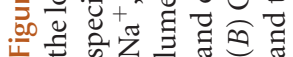

$\varangle$

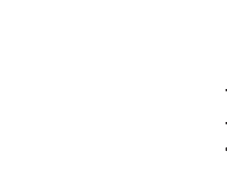


Fluid Transport across Organ-Blood Barriers

on the epithelium. An alternative model for uphill water movement involves water cotransport by solute transporters (Fig. 2F) (Zeuthen and Stein 1994). It has been questioned whether this mechanism would account quantitatively for the large amounts of transported water (Spring 1998; Zeuthen 2002). The $\mathrm{Na}^{+}$/glucose cotransporter SGLT1 has been proposed to transport water against an osmotic gradient (Loo et al. 2002), by incorporating water molecules within the transporter (Adelman et al. 2014). Other transporters that might mediate uphill water flux are NKCC1 in kidney (Hamann et al. 2005; Zeuthen and Macaulay 2012) and a $\mathrm{K}^{+} / \mathrm{Cl}^{-}$cotransporter (Zeuthen $1991 \mathrm{a}, \mathrm{b})$ in the CP. Furthermore, it has been speculated that $\mathrm{Na}^{+} /$glucose cotransport may contribute to paracellular fluid absorption (Turner 2000).

\section{VARIATIONS IN THE ORGANIZATION OF ORGAN-BLOOD BARRIERS}

Different epithelial cells vary dramatically the localization of individual receptors and transporters to perform specific functions required by the host organ. In this section, we discuss organ blood barriers in kidney, brain, and eye and illustrate variations in the localization of transporters implicated in directional fluid transport in three epithelial barriers in these organs, KPT, CP, and RPE (Fig. 3).

\section{Kidney \\ Kidney Glomerular Barrier}

The glomerular filtration barrier filters the blood to remove waste products and excess solutes. From blood to tissue, it displays three components: fenestrated ECs, basement membrane, and podocytes, highly specialized epithe- lial cells with foot processes that interdigitate, forming "filtration slits" (Haraldsson et al. 2008; Scott and Quaggin 2015). The EC fenestrations are $\sim 60 \mathrm{~nm}$ in diameter; therefore, they exclude blood cells but allow the passage of proteins. However, the negatively charged glycocalyx that lines the capillary lumen, together with adsorbed plasma components is believed to be capable of restricting the passage of some molecules (Haraldsson et al. 2008; Scott and Quaggin 2015). The basement membrane is secreted by ECs and podocytes. The laminin matrix meshwork and proteoglycan negative charges limit filtration of intermediate-large molecules (i.e., proteins) (Jarad et al. 2006). Podocyte filtration slits display slit diaphragms, specialized junctional elements (5-15 nm diameter) composed of adhesion, and signaling molecules (nephrin, podocin, Neph1, Nph3, ZO-1, P-cadherin, CD2AP, Densin-180, FAT1), which contribute to regulate the filtration barrier (Haraldsson et al. 2008; Gagliardini et al. 2010). The blood is filtered through EC fenestrae and podocyte filtration slits into the Bowman's (urinary) space, generating an ultrafiltrate with a composition similar to the blood except for the absence of proteins larger than $60 \mathrm{kDa}$.

\section{Kidney Proximal Tubule Barrier}

The KPT reabsorbs $2 / 3$ of the $180 \mathrm{~L}$ of ultrafiltrate generated daily by both kidneys back into the blood circulation. To this end, the KPT's absorptive epithelium organizes its polarity along the classical Koefoed-Johnsen and Ussing model (Fig. 3A) (Koefoed-Johnsen and Ussing 1958; Palmer and Andersen 2008). The $\mathrm{Na}^{+}$, $\mathrm{K}^{+}$-ATPase is localized basolaterally and provides the driving force for primary and secondary active transport. The electrochemical gradient generated by the $\mathrm{Na}^{+}, \mathrm{K}^{+}$-ATPase is used to

Figure 3. (Continued) $\mathrm{NaCl}$ secretion into the CSF provides the driving force for water exit through aquaporin-1. (C) Retinal pigment epithelium: The apical $\mathrm{Na}^{+}, \mathrm{K}^{+}$-ATPase pumps $\mathrm{Na}^{+}$into the cell and removes $\mathrm{K}^{+}$from the subretinal space, which is necessary for the dark current of the photoreceptors. However, net transport of fluid occurs in the apical to basal direction driven by $\mathrm{KCl}$ absorption via apical $\mathrm{Na}^{+}, \mathrm{K}^{+}, 2 \mathrm{Cl}^{-}$cotransport and basolateral exit via $\mathrm{K}^{+}$and $\mathrm{Cl}^{-}$channels. Candidates are Maxi-K, CFTR, Bestrophin, and probably additional $\mathrm{Cl}^{-}$channels. 
P.S. Caceres et al.

reabsorb $\mathrm{Na}^{+}$from the ultrafiltrate via a battery of $\mathrm{Na}^{+}$-coupled symporters and antiporters in the apical side and $\mathrm{Cl}$-/bicarbonate cotransporters in the apical and basal sides. $\mathrm{Na}^{+}$absorption is coupled to other processes such as extrusion of $\mathrm{H}^{+}$via the $\mathrm{Na}^{+} / \mathrm{H}^{+}$exchanger NHE3, crucial for $\mathrm{pH}$ regulation, and uptake of glucose, amino acids, and phosphate into KPT cells (Weinstein 2013). Exit of these solutes via basolateral $\mathrm{Na}^{+}$-independent solute transporters completes their trans-epithelial transport from the ultrafiltrate into the blood.

Most of the net water absorption in the KPT occurs via a transcellular pathway mediated by aquaporin-1 (AQP1) (Schnermann et al. 1998) expressed both apically and basolaterally (Sabolic et al. 1992; Nielsen et al. 1993; Zhang et al. 1993). The remaining fluid flux occurs paracellularly via TJ expressing "leaky" claudins such as claudin-2 (Muto et al. 2010) and possibly claudin-10 and claudin-17 (Krug et al. 2012), which are also selective to cations (e.g., $\mathrm{Na}^{+}, \mathrm{K}^{+}, \mathrm{Ca}^{2+}$, and $\mathrm{Mg}^{2+}$ ) (Bomsztyk et al. 1984; Wilson et al. 1997, 1998; Muto et al. 2010).

\section{Other Kidney-Blood Barriers}

After the KPT reclaims most of the ultrafiltrate through the constitutive process described above, the distal nephron modifies the ultrafiltrate in a regulated fashion to precisely maintain water and electrolyte homeostasis of the internal medium (reviewed in Castaneda-Bueno et al. 2012; Knepper et al. 2015; McCormick and Ellison 2015; Pearce et al. 2015). All distal nephron segments use the same transporter configuration as the KPT, with the $\mathrm{Na}^{+}, \mathrm{K}^{+}$ATPase at the basolateral membrane and a variable complement of apical ion transporters. Water permeability is also controlled by different aquaporin isoforms with distinct properties. The loop of Henle that descends into the medulla operates in tandem with the vasa recta as a countercurrent exchange mechanism that allows urine concentration. The thin descending portion is highly permeable to water because of apical and basolateral AQP1 (Nielsen et al. 1995b), whereas the thin ascending portion is impermeable to water and transports
$\mathrm{Na}^{+}$to the interstitium. The thick ascending portion mediates $\mathrm{NaCl}$ absorption through a basolateral $\mathrm{Na}^{+}, \mathrm{K}^{+}$-ATPase in coordination with apical NKCC2 and NHE3, and a lumenpositive transepithelial electrical gradient that drives cation absorption through the TJs. In the distal convoluted tubule and the collecting duct, $\mathrm{Na}^{+}$absorption is mediated by the apical cotransporter NCC and the $\mathrm{Na}^{+}$channel $\mathrm{ENaC}$, respectively, which use the gradient created by the basolateral $\mathrm{Na}^{+}, \mathrm{K}^{+}$-ATPase. The collecting duct has principal cells, in which water permeability is regulated through translocation of AQP2 to the apical membrane in response to antidiuretic hormone (Nielsen et al. 1995a).

\section{Brain-Blood Barriers}

\section{General Brain-Blood Barrier (BBB)}

The BBB is constituted by a monolayer of continuous non-fenestrated ECs endowed with tight intercellular TJ, which restrict paracellular diffusion of ions and water. The tightness of TJ in BBB ECs is regulated by interactions with astrocytes, pericytes, and the extracellular matrix (ECM). Like epithelial cells, BBB ECs display a polarized distribution of receptors and transporters between the luminal and abluminal side that use energy to transport a net amount of fluid into the brain interstitium (Abbott 2004; Mokgokong et al. 2014; Zhao et al. 2015; Worzfeld and Schwaninger 2016); the mechanisms that control EC polarization remain largely unknown.

\section{Choroid Plexus}

The CP is a secretory epithelium and produces cerebrospinal fluid (CSF), necessary for the normal function of the brain (Fig. 3B). The CSF's ion and nutrient composition is very similar to the blood. Brain ventricles contain $\sim 50-70 \mathrm{ml}$ of CSF; this volume is replaced 4-7 times per day through CP secretion of 500-600 $\mathrm{ml}$ of CSF (Cserr 1971; Wright 1978). This high rate of fluid secretion occurs in the basal-to-apical direction and is achieved via the polarized distribution of apical and basolateral transporters. The $\mathrm{Na}^{+}, \mathrm{K}^{+}$-ATPase and 
Fluid Transport across Organ-Blood Barriers

other transporters, including NKCC1, KCC4, and NHE1, which are normally basolateral in other epithelia, are instead localized apically in the CP. The mechanisms responsible for this atypical transporter localization are not yet fully understood. The $\mathrm{Na}^{+}$pumping activity of the $\mathrm{Na}^{+}, \mathrm{K}^{+}$-ATPase is coordinated with basolateral bicarbonate, $\mathrm{Cl}^{-}$and $\mathrm{Na}^{+}$transporters and with the activity of carbonic anhydrases that promote the intracellular formation of bicarbonate (Davson and Luck 1957; Davson and Segal 1970; Jacobs et al. 2008).

What are the forces that drive fluid transport apically in CP? CSF may have an osmolality slightly higher than blood (Goldberg et al. 1965; Davson and Segal 1996), which has been proposed to drive osmotic movement of water toward the CSF (Damkier et al. 2013). The relative contribution of the paracellular versus transcellular pathways to CSF secretion is still undefined. Transcellular water transport is facilitated by AQP1 (Oshio et al. 2005) and paracellular transport may occur through TJ, which display claudin-2 as well as non-pore-forming claudins (Lippoldt et al. 2000; Wolburg et al. 2001; Kratzer et al. 2012), which classifies CP as an epithelium of "intermediate" TJ (i.e., midway between leaky and tight) based on a reported transepithelial electrical resistance of $\sim 170 \Omega \cdot \mathrm{cm}^{2}$ (Saito and Wright 1983).

\section{Eye-Blood Barriers}

Several circulation systems irrigate different areas within the eye; their structural and functional features are designed to accomplish the particular needs of each region. Whereas, the inner retina is perfused by retinal blood vessels with continuous non-fenestrated capillaries similar to those of the brain, the outer retina is nourished by fenestrated choroidal capillaries, acting in concert with the RPE. In addition, there are other key eye-blood barriers in the eye. Two are involved in the formation (ciliary body) and reabsorption (trabecular meshwork) of the aqueous humor. A third one is the barrier between the cornea, an avascular tissue, and the peri-corneal blood vessels that contribute to corneal nutrition.

\section{The Inner Retina-Blood Barrier (iRBB)}

Because the neural retina is part of the central nervous system, it is not surprising that the $\mathrm{iRBB}$ and $\mathrm{BBB}$ share many structural and functional features. Inner retina capillaries are non-fenestrated, designed to tighly restrict the passage of solutes across the endothelial monolayer. As in the BBB, pericytes and glial cells also participate in the establishment and maintenance of the iRBB (reviewed in Klaassen et al. 2013; Arboleda-Velasquez et al. 2015). In addition, changes in the physical properties of retinal EC basement membrane associated to diabetic retinopathy are causative of EC alterations and barrier dysfunction (Chronopoulos et al. 2010; Yang et al. 2016).

\section{The Outer Retina-Blood Barrier (oRBB)}

The retina accumulates large amounts of water from the metabolic turnover of retinal neurons and photoreceptors and from pressure-induced movement of water from the vitreous body ( $\mathrm{Ha}-$ mann 2002). Water is removed from the inner retina by Muller cells (Moseley et al. 1984; Marmor 1999; Nagelhus et al. 1999) and from the subretinal space by the RPE (Hamann 2002). The RPE, like CP, is a neuroepithelium. However, unlike most other epithelia, the apical plasma membrane (PM) of RPE cells is not free, but is in contact with 50-100 photoreceptors (rods and cones), separated by a virtual compartment, the subretinal space (Fig. 1F). A major task of the RPE is to generate the correct ionic environment for the function of the photoreceptors, controlling tightly the subretinal $\mathrm{K}^{+}$ and $\mathrm{Na}^{+}$levels to allow photoreceptors to generate the "dark current," essential for vision (Strauss 2005). A second major function of RPE is to transport a net amount of fluid in the apical to basal direction, creating a negative pressure in the subretinal space that helps keep the neural retina attached to the RPE (Adijanto et al. 2009). Hence, defective fluid transport by RPE is a cause of important human eye pathologies such as macular edema and retinal detachment (Hamann 2002).

Fluid transport in RPE is driven by the net transport of $\mathrm{Cl}^{-}$and $\mathrm{K}^{+}$in the apical to basal 
P.S. Caceres et al.

direction and is facilitated by AQP1 (Strauss 2005). Lactate, produced in large amounts by the retina and a major food source for photoreceptors, also contributes to fluid transport (Philp et al. 1998; Hamann et al. 2003; Adijanto et al. 2009). Lactate levels in the subretinal space are $3-$ 10 times higher than in the blood (Strauss 2005) and is transported efficiently to the choroid blood by proton-coupled transporters MCT1 and MCT3 at the apical and basolateral membrane of RPE, respectively (Philp et al. 1998).

As in both $\mathrm{CP}$ and $\mathrm{PT}$, this task requires coordinating $\mathrm{Na}^{+}, \mathrm{K}^{+}$-ATPase activity with those of bicarbonate and $\mathrm{Cl}^{-}$transporters. Diurnal variations in the activity of the retina result in changes in the levels of $\mathrm{Na}^{+}, \mathrm{K}^{+}$, and $\mathrm{CO}_{2}$ in the subretinal space, which are balanced by changes in the activity of the various $\mathrm{Na}^{+}, \mathrm{K}^{+}$, $\mathrm{Cl}^{-}$, and bicarbonate transporters (Fig. 2C).

RPE TJs constitute the main barrier between the subretinal space and the choriocapillaris; they generate a paracellular resistance, $\sim 10 \times$ higher than the transcellular resistance, which defines the RPE as a "tight" epithelium (Strauss 2005). Most water moves through AQP1 in the apical and basolateral membranes of RPE. As with KPT and CP, net water transport from RPE to choroid occurs secondarily to ion transport processes (Strauss 2005). However, the organization of fluid transport differs markedly from that of KPT and CP. Like CP, RPE cells localize $\mathrm{Na}^{+}, \mathrm{K}^{+}$-ATPase to the apical PM; however, fluid transport in RPE is in the opposite direction (basal) of fluid transport in CP (apical). Unlike basal fluid transport in KPT, which depends on the net basal transport of $\mathrm{NaCl}$, basal fluid transport in RPE depends on the net transport of $\mathrm{KCl}$. Apical $\mathrm{Na}^{+}, \mathrm{K}^{+}$-ATPase pumps $\mathrm{Na}^{+}$toward the subretinal space generating a $\mathrm{Na}^{+}$gradient that facilitates the entrance of $\mathrm{Cl}^{-}$and $\mathrm{K}^{+}$by a bumetamide-sensitive $\mathrm{Na}^{+}$, $\mathrm{K}^{+}, 2 \mathrm{Cl}^{-}$cotransporter in the apical PM (Kennedy 1990; Miller and Edelman 1990; Bialek et al. 1995; Hu et al. 1996). In mammals, two different genes code for two isoforms of NKCC cotransporters (NKCC1 and NKCC2) and they are both selectively inhibited by bumetanide. To our knowledge, the identity of the apical NKCC cotransporter in RPE has never been deter- mined directly. Based on their affinities for the transported ions, the ionic environment of the subretinal space would allow the proper functioning of NKCC1, but not of NKCC2. The latter is evolutionarily adapted for its function in the extreme ionic environment of the renal medulla, in which $\mathrm{NaCl}$ concentrations can be up to 3-4 times higher than blood. Importantly, NKCC1 is expressed basolaterally in almost all epithelia studied to date (Ginns et al. 1996; He et al. 1997; Delpire et al. 1999; Evans et al. 2000; Shillingford et al. 2002; Del Castillo et al. 2005; Pena-Munzenmayer et al. 2005; Carmosino et al. 2008); hence, if NKCC1 turns out to be the apical bumetanide-sensitive transporter in RPE, this would be another example of inverted polarity in the RPE, similar to the $\mathrm{Na}^{+}, \mathrm{K}^{+}$ATPase. Part of the $\mathrm{K}^{+}$internalized by the $\mathrm{Na}^{+}, \mathrm{K}^{+}$-ATPase is transported back to the subretinal space through the potassium channel Kir7.1, which is tightly coexpressed with $\mathrm{Na}^{+}$, $\mathrm{K}^{+}$-ATPase in various body epithelia. In addition to NKCC, intracellular $\mathrm{Cl}^{-}$and $\mathrm{Na}^{+}$concentrations are also regulated by bicarbonate exchangers, which, together with lactate transporters MCT1 and MCT3, regulate the subretinal and intracellular pH. Accumulation of $\mathrm{Cl}^{-}$results in a high intracellular $\mathrm{Cl}^{-}$concentration $(\sim 60 \mathrm{~mm})$ that, coupled to the favorable transmembrane electric potential across the basolateral PM, promotes exit of $\mathrm{Cl}^{-}$toward the choroidal space, with $\mathrm{K}^{+}$as a counterion. The transporters mediating $\mathrm{K}^{+}$and $\mathrm{Cl}^{-}$exit toward the choroid are poorly characterized. Candidates for this role are a Maxi-K channel, $\mathrm{ClC}-2$, cystic fibrosis transmembrane regulator (CFTR) and Bestrophin-1 (Strauss 2005). ClC-2 is a ubiquitous voltage-gated chloride channel, particularly abundant in epithelial tissues (Grunder et al. 1992; Thiemann et al. 1992; Jentsch 2008), believed to play key roles in transepithelial $\mathrm{Cl}^{-}$transport processes in response to cell swelling and extracellular acidification (Jentsch 2005). Its knockout in mice causes blindness by retinal degeneration and male sterility (Bosl et al. 2001; Edwards et al. 2010) consistent with its presumed localization in blood-tissue epithelial barriers such as the RPE in the outer retina and Sertoli cells in 
the testis (Jentsch 2005; Strauss 2005). Bestrophin-1, encoded by the gene BEST1 (formerly VMD2) causes a group of eye diseases collectively called "bestrophinopathies" (Marmorstein et al. 2009). The best understood is Best vitelliform macular dystrophy (BVMD), a dominant trait characterized electrophysiologically by a normal clinical electroretinogram (ERG) and a diminished light peak. Bestrophin-1 is a $\mathrm{Ca}^{+}$-activated $\mathrm{Cl}^{-}$channel that is expressed in the basolateral PM of RPE and Madin-Darby canine kidney (MDCK) cells (Marmorstein et al. 2000). Many of the mutations that cause human disease cause intracellular retention of Bestrophin-1 (Milenkovic et al. 2011; Johnson et al. 2013, 2014), likely a result of disruption of its tight pentameric structure, recently reported by Long and coworkers (Kane Dickson et al. 2014); however, the signals and mechanisms that mediate its basolateral distribution in both MDCK and RPE cells remain unknown.

\section{EPITHELIAL POLARITY ORGANIZES ORGAN-BLOOD BARRIERS}

As discussed above, the variable organization of ion transporters in different epithelia is key to explain the extent and directionality of fluid transport across epithelia. However, the mechanisms used by the cell to localize these transporters at the correct PM domain and to vary their localization in different epithelial cells remain largely unknown. Here, we will briefly review apical and basolateral sorting mechanisms and discuss some mechanisms that may contribute to the variable localization of ion transporters in different epithelia.

\section{Compartments Involved in Apical- Basolateral Protein Sorting}

The study of the intracellular routes and sorting compartments involved in apical-basolateral PM protein sorting in MDCK cells was initially made possible by the introduction of the prototype polarized epithelial cell line MDCK (Cereijido et al. 1978) and the demonstration that enveloped RNA viruses, for example, influenza and vesicular stomatitis virus, bud from opposite domains of the PM (Rodriguez-Bou- lan and Sabatini 1978; Rodriguez-Boulan and Pendergast 1980). Early studies in the 1980s showed that the envelope proteins of these viruses, for example, influenza hemagglutinin (HA) and VSVG protein are appropriate model apical and basolateral PM proteins and are sorted by epithelial cells using the same compartments and mechanisms used for their own PM proteins. These studies showed that apical and basolateral PM proteins are synthesized in the endoplasmic reticulum (ER) and sorted in the trans-Golgi network (TGN) into different carrier vesicles for delivery to their corresponding PM domains (Fig. 4). Starting in the 1980s, studies by several laboratories have defined the endocytic and recycling routes of MDCK cells, highlighting the presence of separate apical sorting endosomes (ASEs) and basolateral sorting endosomes (BSEs), and two sets of recycling endosomes, the common recycling endosome (CRE) and the apical recycling endosome (ARE), which participate in the sorting of apical and basolateral PM proteins in the recycling route (Fig. 4) (Mostov et al. 2003; RodriguezBoulan and Musch 2005; Rodriguez-Boulan et al. 2005; Mellman and Nelson 2008; Folsch et al. 2009; Apodaca et al. 2012; Rodriguez-Boulan and Macara 2014). Finally, studies in the last decade have shown that TGN and endosomes do not work totally independently but, rather, cooperate in the sorting of PM proteins. Indeed, many newly synthesized PM proteins follow a transendosomal route from the TGN to the PM, with the final sorting decision made at the level of different endosomal compartments (Mellman and Nelson 2008; Folsch et al. 2009; Gonzalez and Rodriguez-Boulan 2009; Weisz and RodriguezBoulan 2009). Preliminary data from our laboratory (R Schreiner, S Salvarezza, and EJ Rodriguez-Boulan, unpubl.) suggest that TGN and CRE are intimately associated (Fig. 4), reflecting a possible coordinated role in protein sorting.

\section{Trafficking Mechanisms Involved in Apical-Basolateral Sorting}

Studies, largely in MDCK cells, have revealed that epithelial cells sort their PM proteins using a dizzying repertoire of apical and basolateral 
P.S. Caceres et al.
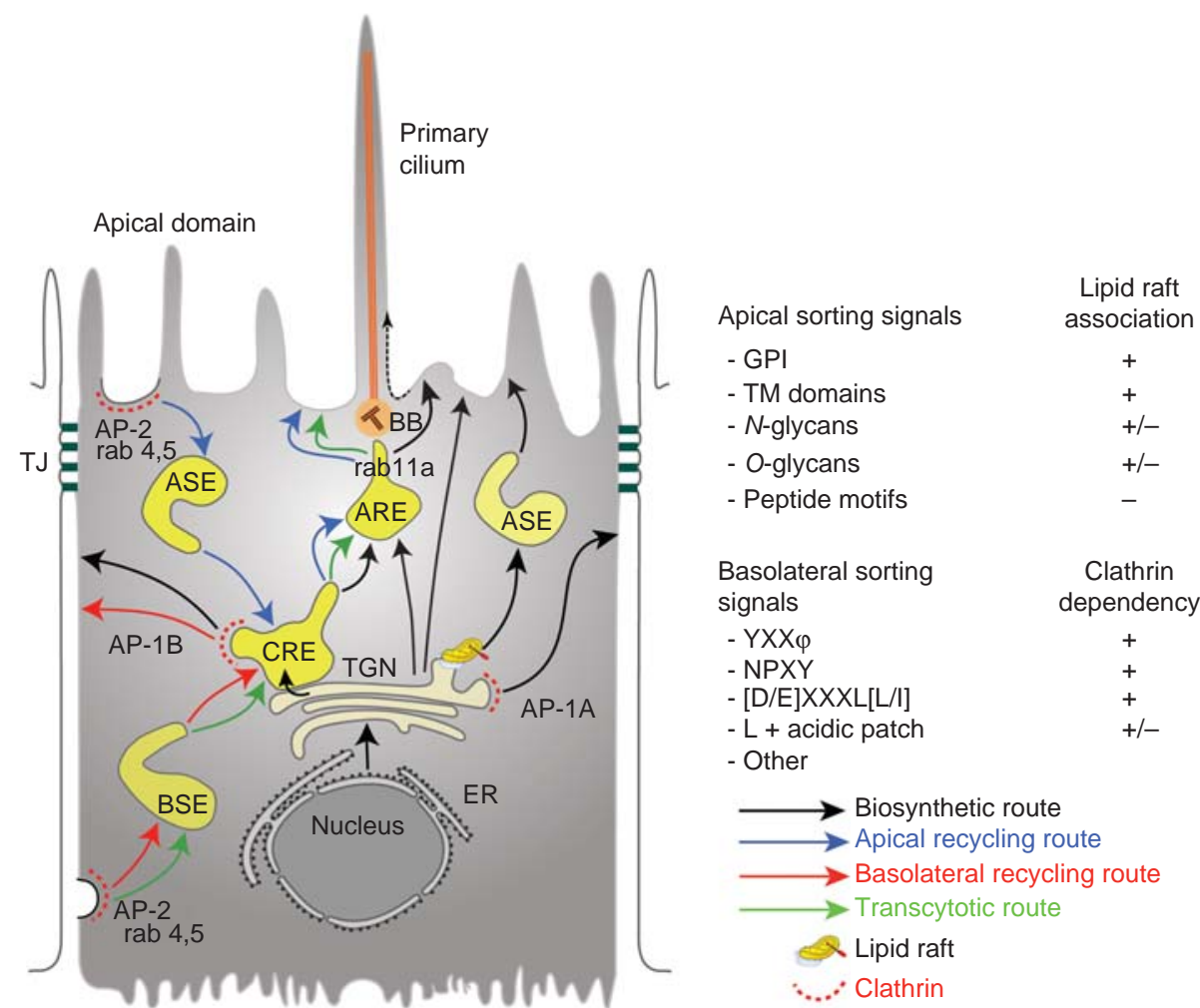

Figure 4. Contributions of protein trafficking to establishing epithelial polarity. Epithelial cells are polarized with apical and basolateral membrane domains separated by tight junctions (TJs). Selective trafficking of domainspecific proteins in and out of these domains allows epithelia to perform their many functions. Apically and basolaterally targeted proteins use various sorting signals (right panel). Apical sorting signals can be associated with lipid rafts and basolateral sorting signals are often dependent on clathrin and the clathrin adaptors AP-1 and AP-2. Different routes are indicated in colored arrows and can traverse several endosomal compartments. Biosynthetic route (black): It originates in the endoplasmic reticulum (ER), then proteins traffic to the Golgi and they are sorted in the trans-Golgi network (TGN). Then proteins are delivered directly to the basolateral or apical membranes, they can traverse apical sorting endosomes (ASEs) and apical recycling endosomes (AREs) en route to the apical membrane or they can reach the basolateral membrane via common recycling endosomes (CREs). Apical recycling route (blue): Proteins are endocytosed from the apical membrane via clathrin, AP-2, and the small GTPases Rab4 and Rab5. They transit to the ASE, CRE, and ARE before reaching the apical membrane again via Rab11a. Basolateral recycling route (red): It originates in the basolateral membrane via endocytosis mediated by clathrin, AP-2, and Rab4 and 5. Proteins transit through the CRE before reaching the basolateral membrane again. Transcytotic route (green): Similar to the basolateral recycling route, it originates in the basolateral membrane, but from the CRE proteins are directed to the ARE and reach the apical membrane. $\mathrm{BB}$, Basal body.

targeting mechanisms, rather than a single binary mechanism. The multiplicity of sorting mechanisms is ontologically explained by the requirement of different epithelia for maximal flexibility in localizing individual transporters apically or basolaterally to perform their tissueor organ-specific functions (Mostov et al. 1992;
Rodriguez-Boulan et al. 2005). Typically, apical sorting signals are complex and may be found in either the luminal, transmembrane, or cytoplasmic domains of the PM protein (Weisz and Rodriguez-Boulan 2009). The first apical sorting signal identified was glycosyl-phosphatidyl inositol (GPI), which mediates attachment of 
GPI-anchored proteins to the PM (Chan et al. 1988; Brown et al. 1989; Lisanti et al. 1989). Because GPI has affinity for PM microdomains enriched in glycosphingolipids and cholesterol, termed "lipid rafts," experiments showing that GPI-anchoring promoted apical targeting of chimeric proteins (Brown et al. 1989; Lisanti et al. 1988, 1989) provided the first experimental support for the lipid raft hypothesis for apical sorting (Simons and van Meer 1988). Subsequent experiments showed that other apical proteins, for example, influenza HA, interacted with lipid rafts (Skibbens et al. 1989). The lipid raft concept is still evolving: current ideas indicate that they are formed in the Golgi complex as very dynamic structures that require aggregation into larger rafts via a variety of proteins (e.g., the tetraspanin MAL1 and certain lectins) to act as sorting platforms (Puertollano et al. 1999; Fullekrug and Simons 2004; Weisz and Rodriguez-Boulan 2009). Lipid raft association is not a universal mechanism for apical trafficking, as many apical proteins are not associated with lipid rafts; some apical proteins are sorted through direct interaction with microtubule motors, for example, rhodopsin (Sung and Tai 2000).

In contrast, sorting of basolateral proteins is mediated by basolateral sorting signals (BLSS), that is, simple peptide motifs in the protein's cytoplasmic domain, often resembling tyrosine (YXXФ, NPXY) and dileucine [D/E]XXXL[L/I] motifs used for clathrin-mediated endocytosis (CME) (Bonifacino and Traub 2003; Gonzalez and Rodriguez-Boulan 2009; Bonifacino 2014; Rodriguez-Boulan and Macara 2014). Other basolateral signals are unrelated to endocytic signals, for example, the tyrosine motifs in LDLR (Matter et al. 1994) and VSVG protein (Thomas et al. 1993), the GDNS motif of transferrin receptor (TfR) (Odorizzi and Trowbridge 1997), the multicomponent basolateral signal of polymeric Ig receptor (Reich et al. 1996), the monoleucine motifs found in CD147 (Deora et al. 2004) and stem cell factor (Wehrle-Haller and Imhof 2001), the $\operatorname{EXEXФ\Phi ~motif~found~}$ in the $\mathrm{M}_{3}$ muscarinic receptor (Iverson et al. 2005), the PXXP motif in the epidermal growth factor receptor (He et al. 2002), and the PDZ- binding domains in syndecan-1 (Maday et al 2008).

During endocytosis, clathrin generates endocytic vesicles via the heterotetrameric clathrin adaptor AP-2, which interacts with endocytic signals via specific pockets characterized in detail by X-ray crystallography (Owen and Evans 1998; Kelly et al. 2008). Likewise, clathrin plays a key role in basolateral traffic at both biosynthetic and recycling routes (Deborde et al. 2008), albeit using a different clathrin adaptor, AP-1. AP- 1 exists as 10 different combinatorial heterotetramers of the medium $(\mu 1 \mathrm{~A}, \mu 1 \mathrm{~B}), \gamma$ $(\gamma 1, \gamma 2), \sigma(\sigma 1 \mathrm{~A}, \sigma 1 \mathrm{~B}, \sigma 1 \mathrm{C})$, and $\beta$ subunits (Bonifacino and Traub 2003; Bonifacino 2014). Two of these variants have been implicated in basolateral sorting. One of them, AP- $1 \mathrm{~B}$, is epithelial-specific and appears to regulate basolateral trafficking in both biosynthetic and recycling routes (Folsch et al. 1999; Ohno et al. 1999; Gan et al. 2002; Cancino et al. 2007; Gravotta et al. 2007). The ubiquitous, highly related AP$1 \mathrm{~A}$ adaptor, which differs from $\mathrm{AP}-1 \mathrm{~B}$ in the medium subunit ( $\mu 1 \mathrm{~A}$ instead of $\mu 1 \mathrm{~B})$, mediates basolateral PM protein sorting proximally to AP-1B, probably at the level of the TGN (Carvajal-Gonzalez et al. 2012; Gravotta et al. 2012; Rodriguez-Boulan et al. 2013). Two other clathrin adaptors, AP-3 and AP-4, have been postulated to participate in basolateral sorting (Nishimura et al. 2002; Simmen et al. 2002), although the original observations supporting this claim have not been followed up. It appears that, although clathrin and clathrin adaptors regulate the localization of many basolateral proteins, there are alternative sorting adaptors involved in basolateral PM localization. To date, these include Naked, involved in basolateral sorting of some epidermal growth factor receptors (Li et al. 2004) and ankyrin G, which participates in cooperation with $\beta 2$ spectrin in basolateral sorting of E-cadherin (Kizhatil et al. 2007).

\section{Domain-Specific Cytoskeletons in Apical- Basolateral Segregation}

PM proteins may be segregated through interactions with asymmetrically distributed cytoskeletal elements. Interactions with apical inter- 
P.S. Caceres et al.

mediate filaments may contribute to the apical localization of PM proteins in epithelia (Rodriguez et al. 1994; Salas et al. 1997). The actin cytoskeleton displays different apical and basolateral organizations (Drenckhahn et al. 1983, 1985; Nelson and Veshnock 1986, 1987b; Rodman et al. 1986; Drenckhahn and Dermietzel 1988). At the apical PM, the actin cytoskeleton contributes to the formation of microvilli through proteins such as Villin (Friederich et al. 1989; Costa de Beauregard et al. 1995) and Ezrin (Takeuchi et al. 1994; Saotome et al. 2004; Fehon et al. 2010). In RPE, Ezrin is localized at both apical and basolateral membranes (Bonilha et al. 1999), interacting with different membrane proteins through different Ezrin-binding adaptors, apical EBP50 and basolateral SAP97 (Bonilha and RodriguezBoulan 2001). For example, Ezrin contributes to the apical localization of transporters like NHE1 (Denker et al. 2000) directly, or indirectly, via EBP50, in the case of CFTR (Short et al. 1998) and NHE3 (Reczek et al. 1997; Murthy et al. 1998).

At the lateral PM, the actin cytoskeleton is organized through association with specific proteins such as catenins (Drees et al. 2005; Yamada et al. 2005), IQGAP1 (Watanabe et al. 2004; Tanos et al. 2015), and Ankyrin (Nelson and Veshnock 1986; Kizhatil and Bennett 2004; Kizhatil et al. 2007). In turn, the basolateral actin cytoskeleton may stabilize certain PM proteins (Drenckhahn et al. 1985, 1993). Such mechanism was initially proposed for $\mathrm{Na}^{+}$, $\mathrm{K}^{+}$-ATPase in MDCK cells, in which a direct interaction of the pump's $\alpha$ subunit with ankyrin promotes its association with the spectrin cytoskeleton, which is concentrated laterally in MDCK cells (Morrow et al. 1989; Nelson and Hammerton 1989; Nelson et al. 1990). In epithelia where the $\mathrm{Na}^{+}, \mathrm{K}^{+}$-ATPase is apical, like the RPE and CP, this association with spectrin and ankyrin may contribute to the inverted polarized distribution of the pump (Gundersen et al. 1991; Marrs et al. 1993; Alper et al. 1994). However, whether these proteins form a complex has not been determined directly and the role played in determining polarized distribution is not clear because spectrin and Ankyrin may be also present at the basolateral membrane in CP (Marrs et al. 1993; Alper et al. 1994).

Mechanisms Controlling Variable Localization of Ion Transporters in Different Epithelia

\section{Differential Expression of Sorting Signals or Mechanisms}

The various strategies used by epithelial cells to localize proteins to apical or basolateral domains may contribute to the variable localization of transporters involved in directional fluid transport. As different sets of signals mediate apical and basolateral trafficking, differential splicing may determine the presence or absence of a specific sorting signal and result in changes in the polarity of a given PM protein. This strategy may be used to change the localization of NKCC1 and aquaporins (Brown and Nielsen 2008; Carmosino et al. 2008). NKCC1 is expressed in the basolateral membrane of most epithelia, directed by a di-leucine motif found in the carboxy-terminal cytoplasmic tail. The dileucine motif is encoded by optionally spliced exon 21. In most epithelia, NKCC1 is expressed with exon 21 but not in neuroectoderm-derived epithelia. This could explain apical targeting of NKCC1 in CP and RPE. However, a report in human cultured RPE cells shows that the messenger for the splice variant that contains the dileucine motif is slightly more abundant that the other splice variant in this epithelium (Vibat et al. 2001).

Not surprisingly, because BLSS are usually dominant over apical sorting signals and many basolateral proteins contain cryptical apical signals, variable expression of a component of the basolateral sorting machinery contributes to the most striking variations in epithelial polarity observed to date. RPE and KPT do not express the clathrin adaptor AP-1B, leading to apical or depolarized localization of a plethora of cognate basolateral proteins in these epithelia (Diaz et al. 2009; Schreiner et al. 2010). These proteins include adhesive PM proteins such as coxsackie adenovirus receptor (CAR), junctional adhesion molecule C (JAMC), and neural cell adhesion molecule (NCAM), hormone re- 
ceptors such as parathyroid hormone receptor (PTHR), and nutrient receptors such as lowdensity lipoprotein receptor (LDLR) and TfR. Clearly, lack of expression of AP-1B must contribute in a significant way to the normal physiology of these epithelia.

\section{Expression of Different Combinations of Transporter Subunits}

Most transporters are either homo- or heterooligomers. For example, the family of P-type ATPases, to which $\mathrm{Na}^{+}, \mathrm{K}^{+}$-ATPase belongs, as well as many amino acid, sugar, and lactate transporters, are heterodimers of a single pass highly glycosylated subunit that acts as a chaperone for intracellular transport, and a multispan transmembrane subunit that constitutes the functional transporter. Studies with monocarboxylate (lactate) transporters, which display variable localization in different epithelia, indicate that sorting signals may be found in the glycosylated subunit (CD147) or in the multispan subunit, according to the particular MCT (Deora et al. 2005; Castorino et al. 2011). Although the basolateral sorting of $\mathrm{Na}^{+}, \mathrm{K}^{+}$ATPase has been attributed to signals in the $\alpha$ (Muth et al. 1998) or $\beta$ (Vagin et al. 2005) subunits, to domain-specific restriction by the ankyrin-spectrin cytoskeleton (Nelson and Veshnock 1987a) or to intercellular adhesion between $\beta$ subunits (Padilla-Benavides et al. 2010), the mechanism that contributes to its reversed apical distribution in RPE or CP remains unknown.

\section{Differential Localization of Domain-Selective Cytoskeleton}

In contrast with MDCK and other kidney cells, which concentrate the ankyrin-spectrin cytoskeleton basolaterally (Drenckhahn et al. 1985; Drenckhahn and Bennett 1987), RPE and CP concentrate this cytoskeleton apically (Gundersen et al. 1991; Alper et al. 1994), which could contribute to the apical localization of $\mathrm{Na}^{+}, \mathrm{K}^{+}$-ATPase in these epithelia. However, this mechanism, although suggested, has not been proven.

\section{CROSS-SIGNALING BETWEEN EXTRACELLULAR MATRIX, PERIVASCULAR, AND ENDOTHELIAL CELLS ORGANIZE ORGAN-BLOOD BARRIERS}

Seminal work by several groups has established a key role of ECM in the development and maintenance of tubular epithelial tissues (Hall et al. 1982; Burute and Thery 2012; Roignot et al. 2013; Overeem et al. 2015). Growing evidence suggests that signals from the basement membrane and perivascular cells may regulate the functional properties of endothelial and epithelial cells in organ-blood barriers. In this section, we review several examples that illustrate such cross-signaling events.

In the brain, the general BBB is formed by ECs, which form part of a "neurovascular unit" that includes vascular smooth muscle cells, pericytes, glial cells (including astrocytes), and neurons (Arboleda-Velasquez et al. 2015; Sweeney et al. 2016). ECs and pericytes share a common basement membrane and the communication between both cell types, as well as their interaction with the ECM and surrounding glial cells, is essential for the integrity of the bloodtissue barrier. Pericytes maintain the BBB by both decreasing endothelial transcellular transport and maintaining proper EC intercellular junctions (Armulik et al. 2010; Bell et al. 2010; Daneman et al. 2010). Furthermore, pericytes are key for the polarization of astrocyte endfeet (Armulik et al. 2010) and, in turn, astrocytesecreted laminin maintains the integrity of $\mathrm{BBB}$ through, at least in part, regulation of pericyte differentiation (Yao et al. 2014). Moreover, astrocytes control the production of matrix metalloproteinase 9 by pericytes, which can degrade the basement membrane and promote the degradation of TJ proteins in ECs (Bell et al. 2012). Consistent with a key role of ECM in the maintenance of $\mathrm{BBB}$ integrity, EC-specific ablation of $\beta 1$ integrin results in the alteration of EC intercellular junctions and BBB disruption (Yamamoto et al. 2015). Thus, it is clear that the cross talk between vascular cells and the stroma in the brain is a complex network whose imbalance disrupts the BBB.

A regulatory role of ECM, ECs, and perivascular cells is emerging for organ-blood barriers 
P.S. Caceres et al.

constituted by epithelial cells. (1) In the kidney, alterations in the composition and structure of the glomerular basement membrane, as well as loss of podocyte-expressed genes involved in ECM attachment, induce the disassembly of podocyte intercellular junctions and failure of the filtration barrier (reviewed in Scott and Quaggin 2015). There is evidence that the glomerular filtration barrier is regulated by cross talk between different glomerular cell types (Bartlett et al. 2016). Furthermore, loss of proteins that control epithelial polarization such as aPKC and the zebrafish Crumbs family member Crb2b results in aberrant podocyte cell-cell junctions and proteinuria (Scott and Quaggin 2015), underscoring the importance of epithelial polarity for proper glomerular barrier function. (2) In the testis, ECM proteins, that is, collagens and laminins, regulate the dynamics of intercellular junctions between Sertoli cells, a key process for spermatogenesis (reviewed in Siu and Cheng 2008). (3) In the gut, there is evidence that intestinal barrier function is controlled by the enteric glia (Aube et al. 2006; Savidge et al. 2007). (4) In the CP, deficit of collagen XVIII (Utriainen et al. 2004) or matrix metalloproteinase 8 (Vandenbroucke et al. 2012) was reported to cause disruptions of CP TJ and the CP barrier. (5) In the outer retina, it has been proposed that neural retina-secreted factors regulate the molecular composition and barrier function of chick RPE TJ (Rahner et al. 2004; Sun et al. 2008). Furthermore, it is well established that aging changes in the RPE basement membrane (named Bruch's membrane, which separates RPE from the fenestrated choroidal capillaries) (Fig. 1) that include thickening and lipid accumulation (Booij et al. 2010) impacts retinal function by impairing the transport of nutrients, oxygen, and waste products between the blood circulation and the outer retina. In addition, these changes may disrupt RPE-ECM interactions leading to functional alterations of the oRBB (Sorkio et al. 2014; I Benedicto, GL Lehmann, EJ Rodriguez-Boulan et al., in prep.). Future work should establish how these changes affect the onset and progression of retinal degenerative diseases, such as age-related macular degeneration.
ECs constitute instructive niches that control organogenesis during development (Lammert et al. 2001; Matsumoto et al. 2001). Exciting recent studies have uncovered key roles of ECs in stem cell renewal (reviewed in Rafii et al. 2016), tissue regeneration (Ding et al. 2010, 2011), and even the acquisition of very specific epithelial features such as apicobasal hepatocyte polarization (Sakaguchi et al. 2008). Recent data in our laboratory suggest that ECs secrete factors that regulate RPE basement membrane and decrease RPE paracellular permeability by modulating the composition and function of RPE TJ, the key constituent of the oRBB (I Benedicto, GL Lehmann, EJ Rodriguez-Boulan et al., in prep.). Interestingly, a similar reduction of paracellular permeability was shown for both KPT and airway epithelial cells when cocultured with ECs (Aydin et al. 2008; Chowdhury et al. 2010). Of note, the absence of ECs in zebrafish embryos results in an abnormal glomerular basement membrane and its defective interaction with podocyte foot processes (Majumdar and Drummond 1999). Thus, it is tempting to speculate that a common mechanism may regulate epithelial-mediated blood barriers throughout the organism, that is, basement membrane remodeling by EC-secreted factors, which in turn modulates epithelial intercellular junctions and barrier function. In addition to the regulation of the paracellular route, there is some evidence suggesting that ECs may also modulate epithelial transcellular transport. Endothelium-released nitric oxide regulates KPT lumen acidification in a $\mathrm{Na}^{+}$-dependent manner (Amorena and Castro 1997), and modulates $\mathrm{Na}^{+}$transport across KPTepithelial cells in vitro by controlling $\mathrm{Na}^{+}, \mathrm{K}^{+}$-ATPase activity (Linas and Repine 1999). Moreover, ECs regulate the expression of several transporters in the KPT epithelial cell line HK-2 (Aydin et al. 2008). In summary, ECs seem to play a key role in the regulation of epithelium-based blood-tissue barriers. Because tissue-specific ECs establish highly specialized vascular niches (Nolan et al. 2013), it is plausible that the microvasculature of different blood-tissue barriers is equipped with specific angiocrine factors needed for the proper maintenance of each particular barrier. Future 
studies are warranted to test this hypothesis, as well as the role of tissue-specific basement membranes and non-EC types in the regulation of epithelium-based blood-tissue barriers.

\section{FUTURE PERSPECTIVES}

More than 30 years of research on epithelial cell polarity have provided invaluable insights into the mechanisms that allow epithelia to perform crucial functions including water and solute transport. As constituents of different organblood barriers, epithelial cells are critical in physiological processes; therefore, disruptions in their biology lead to diseases like Fanconi's syndrome, diabetic nephropathy and hypertension (KPT), hydrocephalus (CP), and macular degeneration (RPE). Similarly, polarization of ECs is key for regulating the transcellular and paracellular routes between blood and tissue, and its imbalance may have profound implications in the onset and progression of pathologies associated to defective fluid transport such as brain and retinal edema.

It is increasingly clear that organ-blood barriers constitute functional units beyond the individual properties of the epithelial and endothelial components. More specifically, ECs along with ECM and other stromal components, play key roles in the regulation of epithelium-based barriers. They supply tissue-specific angiocrine factors and trigger outside-in signaling pathways that may contribute to the maintenance of epithelial polarity and the proper transport of solutes and water across the organ-blood barrier. This is an exciting emerging field with potential clinical applications that deserves further studies.

Despite intensive research, many open questions remain. The mechanisms that regulate epithelial and endothelial polarization are still incompletely understood. Uncovering such mechanisms will contribute to a better understanding of fundamental processes in epithelial physiology like regulation of water transport, or the nature and consequences of the cross talk between the different components of the barrier. Emerging technologies will be instrumental in elucidating these processes. In par- ticular, optical nanoimaging techniques with increasingly higher spatial and temporal resolution, high-throughput approaches to elucidate the properties of such complex system, and powerful gene manipulation technologies will test the translational relevance of the mechanisms discovered. All this considered, advancement in the field will aid, not only in the prevention and treatment of diseases, but also in the development of novel strategies for drug delivery across various organ-blood barriers.

\section{ACKNOWLEDGMENTS}

We thank Jeppe Pretorius and Alan Weinstein for their insights on the manuscript. This work is supported by National Institutes of Health (NIH) Grants GM34107 and EY08538, by a departmental grant from Research to Prevent Blindness and by the Dyson Foundation.

\section{REFERENCES}

Abbott NJ. 2004. Evidence for bulk flow of brain interstitial fluid: Significance for physiology and pathology. Neurochem Int 45: 545-552.

Adelman JL, Sheng Y, Choe S, Abramson J, Wright EM, Rosenberg JM, Grabe M. 2014. Structural determinants of water permeation through the sodium-galactose transporter vSGLT. Biophys J 106: 1280-1289.

Adijanto J, Banzon T, Jalickee S, Wang NS, Miller SS. 2009. $\mathrm{CO}_{2}$-induced ion and fluid transport in human retinal pigment epithelium. J Gen Physiol 133: 603-622.

Alper SL, Stuart-Tilley A, Simmons CF, Brown D, Drenckhahn D. 1994. The fodrin-ankyrin cytoskeleton of choroid plexus preferentially colocalizes with apical $\mathrm{Na}^{+} \mathrm{K}^{+}$ATPase rather than with basolateral anion exchanger AE2. J Clin Invest 93: 1430-1438.

Amorena C, Castro AF. 1997. Control of proximal tubule acidification by the endothelium of the peritubular capillaries. Am J Physiol 272: R691-R694.

Andreoli TE, Schafer JA. 1978. Volume absorption in the pars recta. III: Luminal hypotonicity as a driving force for isotonic volume absorption. Am J Physiol 234: F349F355.

Andreoli TE, Schafer JA, Troutman SL. 1978. Perfusion ratedependence of transepithelial osmosis in isolated proximal convoluted tubules: Estimation of the hydraulic conductance. Kidney Int 14: 263-269.

Apodaca G, Gallo LI, Bryant DM. 2012. Role of membrane traffic in the generation of epithelial cell asymmetry. Nat Cell Biol 14: 1235-1243.

Arboleda-Velasquez JF, Valdez CN, Marko CK, D’Amore PA. 2015. From pathobiology to the targeting of pericytes for 


\section{P.S. Caceres et al.}

the treatment of diabetic retinopathy. Curr Diab Rep 15: 573.

Armulik A, Genove G, Mae M, Nisancioglu MH, Wallgard E, Niaudet C, He L, Norlin J, Lindblom P, Strittmatter K, et al. 2010. Pericytes regulate the blood-brain barrier. $\mathrm{Na}$ ture 468: 557-561.

Aube AC, Cabarrocas J, Bauer J, Philippe D, Aubert P, Doulay F, Liblau R, Galmiche JP, Neunlist M. 2006. Changes in enteric neurone phenotype and intestinal functions in a transgenic mouse model of enteric glia disruption. Gut 55: $630-637$.

Aydin S, Signorelli S, Lechleitner T, Joannidis M, Pleban C Perco P, Pfaller W, Jennings P. 2008. Influence of microvascular endothelial cells on transcriptional regulation of proximal tubular epithelial cells. Am J Physiol Cell Physiol 294: C543-C554.

Bagnat M, Cheung ID, Mostov KE, Stainier DY. 2007. Genetic control of single lumen formation in the zebrafish gut. Nat Cell Biol 9: 954-960.

Bartlett CS, Jeansson M, Quaggin SE. 2016. Vascular growth factors and glomerular disease. Annu Rev Physiol 78: 437-461.

Bell RD, Winkler EA, Sagare AP, Singh I, LaRue B, Deane R, Zlokovic BV. 2010. Pericytes control key neurovascular functions and neuronal phenotype in the adult brain and during brain aging. Neuron 68: 409-427.

Bell RD, Winkler EA, Singh I, Sagare AP, Deane R, Wu Z, Holtzman DM, Betsholtz C, Armulik A, Sallstrom J, et al. 2012. Apolipoprotein E controls cerebrovascular integrity via cyclophilin A. Nature 485: 512-516.

Bentzel CJ, Parsa B, Hare DK. 1969. Osmotic flow across proximal tubule of Necturus: Correlation of physiologic and anatomic studies. Am J Physiol 217: 570-580.

Bialek S, Joseph DP, Miller SS. 1995. The delayed basolateral membrane hyperpolarization of the bovine retinal pigment epithelium: Mechanism of generation. J Physiol 484: 53-67.

Bomsztyk K, George JP, Wright FS. 1984. Effects of luminal fluid anions on calcium transport by proximal tubule. Am J Physiol 246: F600-F608.

Bonifacino JS. 2014. Adaptor proteins involved in polarized sorting. J Cell Biol 204: 7-17.

Bonifacino JS, Traub LM. 2003. Signals for sorting of transmembrane proteins to endosomes and lysosomes. Annu Rev Biochem 72: 395-447.

Bonilha VL, Rodriguez-Boulan E. 2001. Polarity and developmental regulation of two PDZ proteins in the retinal pigment epithelium. Invest Ophthalmol Vis Sci 42: $3274-$ 3282.

Bonilha VL, Finnemann SC, Rodriguez-Boulan E. 1999. Ezrin promotes morphogenesis of apical microvilli and basal infoldings in retinal pigment epithelium. J Cell Biol 147: 1533-1548.

Booij JC, Baas DC, Beisekeeva J, Gorgels TG, Bergen AA. 2010. The dynamic nature of Bruch's membrane. Prog Retin Eye Res 29: 1-18.

Bosl MR, Stein V, Hubner C, Zdebik AA, Jordt SE, Mukhopadhyay AK, Davidoff MS, Holstein AF, Jentsch TJ. 2001. Male germ cells and photoreceptors, both dependent on close cell-cell interactions, degenerate upon $\mathrm{ClC}-2 \mathrm{Cl}^{-}$ channel disruption. EMBO J 20: 1289-1299.
Brown D, Nielsen S. 2008. The cell biology of vasopressin action. In Brenner \& Rector's the kidney (ed. Taal MW, Chertow GM, Marsden PA, Skorecki K, Yu ASL, Brenner BM), pp. 575-594. Elsevier, Philadelphia.

Brown DA, Crise B, Rose JK. 1989. Mechanism of membrane anchoring affects polarized expression of two proteins in MDCK cells. Science 245: 1499-1501.

Burute M, Thery M. 2012. Spatial segregation between cellcell and cell-matrix adhesions. Curr Opin Cell Biol 24: $628-636$.

Cancino J, Torrealba C, Soza A, Yuseff MI, Gravotta D, Henklein P, Rodriguez-Boulan E, Gonzalez A. 2007. Antibody to AP1B adaptor blocks biosynthetic and recycling routes of basolateral proteins at recycling endosomes. Mol Biol Cell 18: 4872-4884.

Carmosino M, Gimenez I, Caplan M, Forbush B. 2008. Exon loss accounts for differential sorting of $\mathrm{Na}-\mathrm{K}-\mathrm{Cl}$ cotransporters in polarized epithelial cells. Mol Biol Cell 19: 4341-4351.

Carvajal-Gonzalez JM, Gravotta D, Mattera R, Diaz F, Perez Bay A, Roman AC, Schreiner RP, Thuenauer R, Bonifacino JS, Rodriguez-Boulan E. 2012. Basolateral sorting of the coxsackie and adenovirus receptor through interaction of a canonical YXX $\phi$ motif with the clathrin adaptors AP-1A and AP-1B. Proc Natl Acad Sci 109: 38203825.

Castaneda-Bueno M, Arroyo JP, Gamba G. 2012. Independent regulation of $\mathrm{Na}^{+}$and $\mathrm{K}^{+}$balance by the kidney. Med Princ Pract 21: 101-114.

Castorino JJ, Deborde S, Deora A, Schreiner R, GallagherColombo SM, Rodriguez-Boulan E, Philp NJ. 2011. Basolateral sorting signals regulating tissue-specific polarity of heteromeric monocarboxylate transporters in epithelia. Traffic 12: 483-498.

Cereijido M, Robbins ES, Dolan WJ, Rotunno CA, Sabatini DD. 1978. Polarized monolayers formed by epithelial cells on a permeable and translucent support. J Cell Biol 77: $853-880$.

Chan BL, Lisanti MP, Rodriguez-Boulan E, Saltiel AR. 1988. Insulin-stimulated release of lipoprotein lipase by metabolism of its phosphatidylinositol anchor. Science 241: 1670-1672.

Chowdhury F, Howat WJ, Phillips GJ, Lackie PM. 2010. Interactions between endothelial cells and epithelial cells in a combined cell model of airway mucosa: Effects on tight junction permeability. Exp Lung Res 36: 1-11.

Chronopoulos A, Tang A, Beglova E, Trackman PC, Roy S. 2010. High glucose increases lysyl oxidase expression and activity in retinal endothelial cells: Mechanism for compromised extracellular matrix barrier function. Diabetes 59: 3159-3166.

Costa de Beauregard MA, Pringault E, Robine S, Louvard D. 1995. Suppression of villin expression by antisense RNA impairs brush border assembly in polarized epithelial intestinal cells. EMBO J 14: 409-421.

Cserr HF. 1971. Physiology of the choroid plexus. Physiol Rev 51: 273-311.

Curran PF. 1960. Na, Cl, and water transport by rat ileum in vitro. J Gen Physiol 43: 1137-1148.

Curran PF, Macintosh JR. 1962. A model system for biological water transport. Nature 193: 347-348. 
Fluid Transport across Organ-Blood Barriers

Curran PF, Solomon AK. 1957. Ion and water fluxes in the ileum of rats. J Gen Physiol 41: 143-168.

Damkier HH, Brown PD, Praetorius J. 2013. Cerebrospinal fluid secretion by the choroid plexus. Physiol Rev 93: 1847-1892.

Daneman R, Zhou L, Kebede AA, Barres BA. 2010. Pericytes are required for blood-brain barrier integrity during embryogenesis. Nature 468: 562-566.

Davson H, Luck CP. 1957. The effect of acetazoleamide on the chemical composition of the aqueous humour and cerebrospinal fluid of some mammalian species and on the rate of turnover of ${ }^{24} \mathrm{Na}$ in these fluids. J Physiol 137: 279-293.

Davson H, Segal MB. 1970. The effects of some inhibitors and accelerators of sodium transport on the turnover of ${ }^{22} \mathrm{Na}$ in the cerebrospinal fluid and the brain. J Physiol 209: $131-153$.

Davson H, Segal MB. 1996. Physiology of the CSF and bloodbrain barriers, p. 1832. CRC, Boca Raton, FL.

Deborde S, Perret E, Gravotta D, Deora A, Salvarezza S, Schreiner R, Rodriguez-Boulan E. 2008. Clathrin is a key regulator of basolateral polarity. Nature 452: 719 723.

Del Castillo IC, Fedor-Chaiken M, Song JC, Starlinger V, Yoo J, Matlin KS, Matthews JB. 2005. Dynamic regulation of $\mathrm{Na}^{+}-\mathrm{K}^{+}-2 \mathrm{Cl}^{-}$cotransporter surface expression by PKC- $\varepsilon$ in $\mathrm{Cl}^{-}$-secretory epithelia. Am J Physiol Cell Physiol 289: C1332-C1342.

Delpire E, Lu J, England R, Dull C, Thorne T. 1999. Deafness and imbalance associated with inactivation of the secretory $\mathrm{Na}-\mathrm{K}-2 \mathrm{Cl}$ co-transporter. Nat Genet 22: $192-$ 195.

Denker SP, Huang DC, Orlowski J, Furthmayr H, Barber DL. 2000. Direct binding of the $\mathrm{Na}-\mathrm{H}$ exchanger NHE1 to ERM proteins regulates the cortical cytoskeleton and cell shape independently of $\mathrm{H}^{+}$translocation. Mol Cell 6: $1425-1436$.

Deora AA, Gravotta D, Kreitzer G, Hu J, Bok D, RodriguezBoulan E. 2004. The basolateral targeting signal of CD147 (EMMPRIN) consists of a single leucine and is not recognized by retinal pigment epithelium. Mol Biol Cell 15: 4148-4165.

Deora AA, Philp N, Hu J, Bok D, Rodriguez-Boulan E. 2005. Mechanisms regulating tissue-specific polarity of monocarboxylate transporters and their chaperone CD147 in kidney and retinal epithelia. Proc Natl Acad Sci 102: $16245-16250$.

de Rougemont J, Ames A III, Nesbett FB, Hofmann HF 1960. Fluid formed by choroid plexus; a technique for its collection and a comparison of its electrolyte composition with serum and cisternal fluids. J Neurophysiol 23: 485-495.

Diamond JM. 1962. The mechanism of water transport by the gall-bladder. J Physiol 161: 503-527.

Diamond JM, Bossert WH. 1967. Standing-gradient osmotic flow. A mechanism for coupling of water and solute transport in epithelia. J Gen Physiol 50: 2061-2083.

Diaz F, Gravotta D, Deora A, Schreiner R, Schoggins J, FalckPedersen E, Rodriguez-Boulan E. 2009. Clathrin adaptor AP1B controls adenovirus infectivity of epithelial cells. Proc Natl Acad Sci 106: 11143-11148.
Ding BS, Nolan DJ, Butler JM, James D, Babazadeh AO, Rosenwaks Z, Mittal V, Kobayashi H, Shido K, Lyden D, et al. 2010. Inductive angiocrine signals from sinusoidal endothelium are required for liver regeneration. Nature 468: $310-315$.

Ding BS, Nolan DJ, Guo P, Babazadeh AO, Cao Z, Rosenwaks Z, Crystal RG, Simons M, Sato TN, Worgall S, et al. 2011. Endothelial-derived angiocrine signals induce and sustain regenerative lung alveolarization. Cell 147: 539-553.

Drees F, Pokutta S, Yamada S, Nelson WJ, Weis WI. 2005. $\alpha$-Catenin is a molecular switch that binds E-cadherin$\beta$-catenin and regulates actin-filament assembly. Cell 123: 903-915.

Drenckhahn D, Bennett V. 1987. Polarized distribution of Mr 210,000 and 190,000 analogs of erythrocyte ankyrin along the plasma membrane of transporting epithelia, neurons and photoreceptors. Eur J Cell Biol 43: 479-486.

Drenckhahn D, Dermietzel R. 1988. Organization of the actin filament cytoskeleton in the intestinal brush border: A quantitative and qualitative immunoelectron microscope study. J Cell Biol 107: 1037-1048.

Drenckhahn D, Hofmann HD, Mannherz HG. 1983. Evidence for the association of villin with core filaments and rootlets of intestinal epithelial microvilli. Cell Tissue Res 228: 409-414.

Drenckhahn D, Schluter K, Allen DP, Bennett V. 1985. Colocalization of band 3 with ankyrin and spectrin at the basal membrane of intercalated cells in the rat kidney. Science 230: 1287-1289.

Drenckhahn D, Jons T, Kollert-Jons A, Koob R, Kraemer D, Wagner S. 1993. Cytoskeleton and epithelial polarity. Renal Physiol Biochem 16: 6-14.

Durbin RP. 1960. Osmotic flow of water across permeable cellulose membranes. J Gen Physiol 44: 315-326.

Edwards MM, Marin de Evsikova C, Collin GB, Gifford E, Wu J, Hicks WL, Whiting C, Varvel NH, Maphis N, Lamb BT, et al. 2010. Photoreceptor degeneration, azoospermia, leukoencephalopathy, and abnormal RPE cell function in mice expressing an early stop mutation in CLCN2. Invest Ophthalmol Vis Sci 51: 3264-3272.

Evans RL, Park K, Turner RJ, Watson GE, Nguyen HV, Dennett MR, Hand AR, Flagella M, Shull GE, Melvin JE. 2000. Severe impairment of salivation in $\mathrm{Na}^{+} / \mathrm{K}^{+} / 2 \mathrm{Cl}^{-}$ cotransporter (NKCC1)-deficient mice. J Biol Chem 275: 26720-26726.

Farquhar MG, Palade GE. 1964. Functional organization of amphibian skin. Proc Natl Acad Sci 51: 569-577.

Fehon RG, McClatchey AI, Bretscher A. 2010. Organizing the cell cortex: The role of ERM proteins. Nat Rev Mol Cell Biol 11: 276-287.

Folsch H, Ohno H, Bonifacino JS, Mellman I. 1999. A novel clathrin adaptor complex mediates basolateral targeting in polarized epithelial cells. Cell 99: 189-198.

Folsch H, Mattila PE, Weisz OA. 2009. Taking the scenic route: Biosynthetic traffic to the plasma membrane in polarized epithelial cells. Traffic 10: 972-981.

Friederich E, Huet C, Arpin M, Louvard D. 1989. Villin induces microvilli growth and actin redistribution in transfected fibroblasts. Cell 59: 461-475. 


\section{P.S. Caceres et al.}

Fullekrug J, Simons K. 2004. Lipid rafts and apical membrane traffic. Ann NY Acad Sci 1014: 164-169.

Gagliardini E, Conti S, Benigni A, Remuzzi G, Remuzzi A. 2010. Imaging of the porous ultrastructure of the glomerular epithelial filtration slit. J Am Soc Nephrol 21: 20812089.

Gan Y, McGraw TE, Rodriguez-Boulan E. 2002. The epithelial-specific adaptor AP1B mediates post-endocytic recycling to the basolateral membrane. Nat Cell Biol 4: 605609.

Ginns SM, Knepper MA, Ecelbarger CA, Terris J, He X, Coleman RA, Wade JB. 1996. Immunolocalization of the secretory isoform of $\mathrm{Na}-\mathrm{K}-\mathrm{Cl}$ cotransporter in rat renal intercalated cells. J Am Soc Nephrol 7: $2533-$ 2542.

Goldberg NB, Sawinski VJ, Goldberg AF. 1965. Human cerebrospinal fluid osmolality at $37^{\circ} \mathrm{C}$. Anesthesiology 26: 829 .

Gonzalez A, Rodriguez-Boulan E. 2009. Clathrin and AP1B: Key roles in basolateral trafficking through trans-endosomal routes. FEBS Lett 583: 3784-3795.

Gravotta D, Deora A, Perret E, Oyanadel C, Soza A, Schreiner R, Gonzalez A, Rodriguez-Boulan E. 2007. AP1B sorts basolateral proteins in recycling and biosynthetic routes of MDCK cells. Proc Natl Acad Sci 104: 1564-1569.

Gravotta D, Carvajal-Gonzalez JM, Mattera R, Deborde S, Banfelder JR, Bonifacino JS, Rodriguez-Boulan E. 2012 The clathrin adaptor AP-1A mediates basolateral polarity. Dev Cell 22: 811-823.

Grunder S, Thiemann A, Pusch M, Jentsch TJ. 1992. Regions involved in the opening of CIC-2 chloride channel by voltage and cell volume. Nature 360: 759-762.

Gundersen D, Orlowski J, Rodriguez-Boulan E. 1991. Apical polarity of $\mathrm{Na}$, K-ATPase in retinal pigment epithelium is linked to a reversal of the ankyrin-fodrin submembrane cytoskeleton. J Cell Biol 112: 863-872.

Hall HG, Farson DA, Bissell MJ. 1982. Lumen formation by epithelial cell lines in response to collagen overlay: A morphogenetic model in culture. Proc Natl Acad Sci 79: 4672-4676.

Hamann S. 2002. Molecular mechanisms of water transport in the eye. Int Rev Cytol 215: 395-431.

Hamann S, Kiilgaard JF, la Cour M, Prause JU, Zeuthen T. 2003. Cotransport of $\mathrm{H}^{+}$, lactate, and $\mathrm{H}_{2} \mathrm{O}$ in porcine retinal pigment epithelial cells. Exp Eye Res 76: 493-504.

Hamann S, Herrera-Perez JJ, Bundgaard M, Alvarez-Leefmans FJ, Zeuthen T. 2005. Water permeability of $\mathrm{Na}^{+}-$ $\mathrm{K}^{+}-2 \mathrm{Cl}^{-}$cotransporters in mammalian epithelial cells. J Physiol 568: 123-135.

Haraldsson B, Nystrom J, Deen WM. 2008. Properties of the glomerular barrier and mechanisms of proteinuria. Physiol Rev 88: 451-487.

He X, Tse CM, Donowitz M, Alper SL, Gabriel SE, Baum BJ. 1997. Polarized distribution of key membrane transport proteins in the rat submandibular gland. Pflugers Arch 433: $260-268$.

He C, Hobert M, Friend L, Carlin C. 2002. The epidermal growth factor receptor juxtamembrane domain has multiple basolateral plasma membrane localization determi- nants, including a dominant signal with a polyproline core. J Biol Chem 277: 38284-38293.

Heisey SR, Held D, Pappenheimer JR. 1962. Bulk flow and diffusion in the cerebrospinal fluid system of the goat. $A m$ J Physiol 203: 775-781.

Hu JG, Gallemore RP, Bok D, Frambach DA. 1996. Chloride transport in cultured fetal human retinal pigment epithelium. Exp Eye Res 62: 443-448.

Iverson HA, Fox D III, Nadler LS, Klevit RE, Nathanson NM. 2005. Identification and structural determination of the $\mathrm{M}_{3}$ muscarinic acetylcholine receptor basolateral sorting signal. J Biol Chem 280: 24568-24575.

Jacobs S, Ruusuvuori E, Sipila ST, Haapanen A, Damkier HH, Kurth I, Hentschke M, Schweizer M, Rudhard Y, Laatikainen LM, et al. 2008. Mice with targeted Slc4a10 gene disruption have small brain ventricles and show reduced neuronal excitability. Proc Natl Acad Sci 105: $311-316$.

Jarad G, Cunningham J, Shaw AS, Miner JH. 2006. Proteinuria precedes podocyte abnormalities in $\mathrm{Lamb2}^{-/-}$ mice, implicating the glomerular basement membrane as an albumin barrier. J Clin Invest 116: 2272-2279.

Jentsch TJ. 2005. Chloride transport in the kidney: Lessons from human disease and knockout mice. J Am Soc Nephrol 16: $1549-1561$.

Jentsch TJ. 2008. CLC chloride channels and transporters: From genes to protein structure, pathology and physiology. Crit Rev Biochem Mol Biol 43: 3-36.

Johnson AA, Lee YS, Stanton JB, Yu K, Hartzell CH, Marmorstein LY, Marmorstein AD. 2013. Differential effects of Best disease causing missense mutations on bestrophin-1 trafficking. Hum Mol Genet 22: 4688-4697.

Johnson AA, Lee YS, Chadburn AJ, Tammaro P, Manson FD, Marmorstein LY, Marmorstein AD. 2014. Disease-causing mutations associated with four bestrophinopathies exhibit disparate effects on the localization, but not the oligomerization, of Bestrophin-1. Exp Eye Res 121: $74-85$.

Kane Dickson V, Pedi L, Long SB. 2014. Structure and insights into the function of a Ca${ }^{2+}$-activated $\mathrm{Cl}^{-}$channel. Nature 516: 213-218.

Kaye GI, Wheeler HO, Whitlock RT, Lane N. 1966. Fluid transport in the rabbit gallbladder. A combined physiological and electron microscopic study. J Cell Biol 30: 237-268.

Kelly BT, McCoy AJ, Spate K, Miller SE, Evans PR, Honing S, Owen DJ. 2008. A structural explanation for the binding of endocytic dileucine motifs by the AP2 complex. $\mathrm{Na}$ ture 456: 976-979.

Kennedy BG. 1990. $\mathrm{Na}^{+}-\mathrm{K} 4-\mathrm{Cl}^{-}$cotransport in cultured cells derived from human retinal pigment epithelium. Am J Physiol 259: C29-34.

Khan LA, Zhang H, Abraham N, Sun L, Fleming JT, Buechner M, Hall DH, Gobel V. 2013. Intracellular lumen extension requires ERM-1-dependent apical membrane expansion and AQP-8-mediated flux. Nat Cell Biol 15: $143-156$.

Kizhatil K, Bennett V. 2004. Lateral membrane biogenesis in human bronchial epithelial cells requires $190-\mathrm{kDa}$ ankyrin-G. J Biol Chem 279: 16706-16714. 
Kizhatil K, Yoon W, Mohler PJ, Davis LH, Hoffman JA, Bennett V. 2007. Ankyrin-G and $\beta 2$-spectrin collaborate in biogenesis of lateral membrane of human bronchial epithelial cells. J Biol Chem 282: 2029-2037.

Klaassen I, Van Noorden CJ, Schlingemann RO. 2013. Molecular basis of the inner blood-retinal barrier and its breakdown in diabetic macular edema and other pathological conditions. Prog Retin Eye Res 34: 19-48.

Knepper MA, Kwon TH, Nielsen S. 2015. Molecular physiology of water balance. N Engl J Med 372: 1349-1358.

Koefoed-Johnsen V, Ussing HH. 1958. The nature of the frog skin potential. Acta Physiol Scand 42: 298-308.

Kolotuev I, Hyenne V, Schwab Y, Rodriguez D, Labouesse M. 2013. A pathway for unicellular tube extension depending on the lymphatic vessel determinant Proxl and on osmoregulation. Nat Cell Biol 15: 157-168.

Kratzer I, Vasiljevic A, Rey C, Fevre-Montange M, Saunders N, Strazielle N, Ghersi-Egea JF. 2012. Complexity and developmental changes in the expression pattern of claudins at the blood-CSF barrier. Histochem Cell Biol 138: 861-879.

Krug SM, Gunzel D, Conrad MP, Lee IF, Amasheh S, Fromm M, Yu AS. 2012. Charge-selective claudin channels. Ann NYAcad Sci 1257: 20-28.

Kyte J. 1976. Immunoferritin determination of the distribution of $\left(\mathrm{Na}^{+}+\mathrm{K}^{+}\right)$ATPase over the plasma membranes of renal convoluted tubules. II: Proximal segment. J Cell Biol 68: 304-318.

Lammert E, Cleaver O, Melton D. 2001. Induction of pancreatic differentiation by signals from blood vessels. Science 294: 564-567.

Li C, Franklin JL, Graves-Deal R, Jerome WG, Cao Z, Coffey RJ. 2004. Myristoylated Naked2 escorts transforming growth factor $\alpha$ to the basolateral plasma membrane of polarized epithelial cells. Proc Natl Acad Sci 101: 55715576.

Linas SL, Repine JE. 1999. Endothelial cells regulate proximal tubule epithelial cell sodium transport. Kidney Int 55: $1251-1258$.

Lippoldt A, Liebner S, Andbjer B, Kalbacher H, Wolburg H, Haller H, Fuxe K. 2000. Organization of choroid plexus epithelial and endothelial cell tight junctions and regulation of claudin- $1,-2$ and -5 expression by protein kinase C. Neuroreport 11: 1427-1431.

Lisanti MP, Sargiacomo M, Graeve L, Saltiel AR, RodriguezBoulan E. 1988. Polarized apical distribution of glycosylphosphatidylinositol-anchored proteins in a renal epithelial cell line. Proc Natl Acad Sci 85: 9557-9561.

Lisanti M, Caras IP, Davitz MA, Rodriguez-Boulan E. 1989 A glycophospholipid membrane anchor acts as an apical targeting signal in polarized epithelial cells. J Cell Biol 109: $2145-2156$

Loo DD, Wright EM, Zeuthen T. 2002. Water pumps. J Physiol 542: 53-60.

Lowery LA, Sive H. 2005. Initial formation of zebrafish brain ventricles occurs independently of circulation and requires the nagie oko and snakehead/atplala.1 gene products. Development 132: 2057-2067.

Maday S, Anderson E, Chang HC, Shorter J, Satoh A, Sfakianos J, Folsch H, Anderson JM, Walther Z, Mellman I. 2008. A PDZ-binding motif controls basolateral targeting of syndecan-1 along the biosynthetic pathway in polarized epithelial cells. Traffic 9: 1915-1924.

Majumdar A, Drummond IA. 1999. Podocyte differentiation in the absence of endothelial cells as revealed in the zebrafish avascular mutant, cloche. Dev Genet 24: 220 229.

Marmor MF. 1999. Mechanisms of fluid accumulation in retinal edema. Doc Ophthalmol 97: 239-249.

Marmorstein AD, Marmorstein LY, Rayborn M, Wang X, Hollyfield JG, Petrukhin K. 2000. Bestrophin, the product of the Best vitelliform macular dystrophy gene (VMD2), localizes to the basolateral plasma membrane of the retinal pigment epithelium. Proc Natl Acad Sci 97: 12758-12763.

Marmorstein AD, Cross HE, Peachey NS. 2009. Functional roles of bestrophins in ocular epithelia. Prog Retin Eye Res 28: 206-226.

Marrs JA, Napolitano EW, Murphy-Erdosh C, Mays RW, Reichardt LF, Nelson WJ. 1993. Distinguishing roles of the membrane-cytoskeleton and cadherin mediated cellcell adhesion in generating different $\mathrm{Na}^{+}, \mathrm{K}^{+}$-ATPase distributions in polarized epithelia. J Cell Biol 123: 149-164.

Matsumoto K, Yoshitomi H, Rossant J, Zaret KS. 2001. Liver organogenesis promoted by endothelial cells prior to vascular function. Science 294: 559-563.

Matter K, Yamamoto EM, Mellman I. 1994. Structural requirements and sequence motifs for polarized sorting and endocytosis of LDL and Fc receptors in MDCK cells. J Cell Biol 126: 991-1004.

Maunsbach AB, Boulpaep EL. 1980. Hydrostatic pressure changes related to paracellular shunt ultrastructure in proximal tubule. Kidney Int 17: 732-748.

McCormick JA, Ellison DH. 2015. Distal convoluted tubule. Comp Physiol 5: 45-98.

Mellman I, Nelson WJ. 2008. Coordinated protein sorting, targeting and distribution in polarized cells. Nat Rev Mol Cell Biol 9: 833-845.

Milenkovic VM, Rohrl E, Weber BH, Strauss O. 2011. Disease-associated missense mutations in bestrophin-1 affect cellular trafficking and anion conductance. J Cell Sci 124: $2988-2996$

Miller SS, Edelman JL. 1990. Active ion transport pathways in the bovine retinal pigment epithelium. J Physiol 424: 283-300.

Miller SS, Hughes BA, Machen TE. 1982. Fluid transport across retinal pigment epithelium is inhibited by cyclic AMP. Proc Natl Acad Sci 79: 2111-2115.

Mokgokong R, Wang S, Taylor CJ, Barrand MA, Hladky SB. 2014. Ion transporters in brain endothelial cells that contribute to formation of brain interstitial fluid. Pflugers Arch 466: 887-901.

Morrow JS, Cianci CD, Ardito T, Mann AS, Kashgarian M. 1989. Ankyrin links fodrin to the $\alpha$ subunit of $\mathrm{Na}, \mathrm{K}$ ATPase in Madin-Darby canine kidney cells and in intact renal tubule cells. J Cell Biol 108: 455-465.

Moseley H, Foulds WS, Allan D, Kyle PM. 1984. Routes of clearance of radioactive water from the rabbit vitreous. $\mathrm{Br}$ J Ophthalmol 68: 145-151. 


\section{P.S. Caceres et al.}

Mostov K, Apodaca G, Aroeti B, Okamoto C. 1992. Plasma membrane protein sorting in polarized epithelial cells. J Cell Biol 116: 577-583.

Mostov K, Su T, ter Beest M. 2003. Polarized epithelial membrane traffic: Conservation and plasticity. Nat Cell Biol 5: 287-293.

Murthy A, Gonzalez-Agosti C, Cordero E, Pinney D, Candia C, Solomon F, Gusella J, Ramesh V. 1998. NHE-RF, a regulatory cofactor for $\mathrm{Na}^{+}-\mathrm{H}^{+}$exchange, is a common interactor for merlin and ERM (MERM) proteins. J Biol Chem 273: 1273-1276.

Muth TR, Gottardi CJ, Roush DL, Caplan MJ. 1998. A basolateral sorting signal is encoded in the $\alpha$-subunit of $\mathrm{Na}-\mathrm{K}$-ATPase. Am J Physiol 274: C688-696.

Muto S, Hata M, Taniguchi J, Tsuruoka S, Moriwaki K, Saitou M, Furuse K, Sasaki H, Fujimura A, Imai M, et al. 2010. Claudin-2-deficient mice are defective in the leaky and cation-selective paracellular permeability properties of renal proximal tubules. Proc Natl Acad Sci 107: 8011-8016.

Nagelhus EA, Horio Y, Inanobe A, Fujita A, Haug FM, Nielsen S, Kurachi Y, Ottersen OP. 1999. Immunogold evidence suggests that coupling of $\mathrm{K}^{+}$siphoning and water transport in rat retinal Muller cells is mediated by a coenrichment of Kir4.1 and AQP4 in specific membrane domains. Glia 26: 47-54.

Nelson WJ, Hammerton RW. 1989. A membrane-cytoskeletal complex containing $\mathrm{Na}^{+}, \mathrm{K}^{+}$-ATPase, ankyrin, and fodrin in Madin-Darby canine kidney (MDCK) cells: Implications for the biogenesis of epithelial cell polarity. J Cell Biol 108: 893-902.

Nelson WJ, Veshnock PJ. 1986. Dynamics of membraneskeleton (fodrin) organization during development of polarity in Madin-Darby canine kidney epithelial cells. J Cell Biol 103: 1751-1765.

Nelson WJ, Veshnock PJ. 1987a. Ankyrin binding to $\mathrm{Na}^{+}$ $+\mathrm{K}^{+}$)ATPase and implications for the organization of membrane domains in polarized cells. Nature 328: 533536.

Nelson WJ, Veshnock PJ. 1987b. Modulation of fodrin (membrane skeleton) stability by cell-cell contact in Madin-Darby canine kidney epithelial cells. J Cell Biol 104: $1527-1537$.

Nelson WJ, Shore EM, Wang AZ, Hammerton RW. 1990. Identification of a membrane-cytoskeletal complex containing the cell adhesion molecule uvomorulin (E-cadherin), ankyrin, and fodrin in Madin-Darby canine kidney epithelial cells. J Cell Biol 110: 349-357.

Nielsen S, Smith BL, Christensen EI, Knepper MA, Agre P. 1993. CHIP28 water channels are localized in constitutively water-permeable segments of the nephron. J Cell Biol 120: 371-383.

Nielsen S, Chou CL, Marples D, Christensen EI, Kishore BK Knepper MA. 1995a. Vasopressin increases water permeability of kidney collecting duct by inducing translocation of aquaporin-CD water channels to plasma membrane. Proc Natl Acad Sci 92: 1013-1017.

Nielsen S, Pallone T, Smith BL, Christensen EI, Agre P, Maunsbach AB. 1995b. Aquaporin-1 water channels in short and long loop descending thin limbs and in descending vasa recta in rat kidney. Am J Physiol 268: F1023-1037.
Nishimura N, Plutner H, Hahn K, Balch WE. 2002. The delta subunit of AP-3 is required for efficient transport of VSV-G from the trans-Golgi network to the cell surface. Proc Natl Acad Sci 99: 6755-6760.

Nolan DJ, Ginsberg M, Israely E, Palikuqi B, Poulos MG, James D, Ding BS, Schachterle W, Liu Y, Rosenwaks Z, et al. 2013. Molecular signatures of tissue-specific microvascular endothelial cell heterogeneity in organ maintenance and regeneration. Dev Cell 26: 204219.

Odorizzi G, Trowbridge IS. 1997. Structural requirements for basolateral sorting of the human transferrin receptor in the biosynthetic and endocytic pathways of Madin-Darby canine kidney cells. J Cell Biol 137: 1255-1264.

Ohno H, Tomemori T, Nakatsu F, Okazaki Y, Aguilar RC, Foelsch H, Mellman I, Saito T, Shirasawa T, Bonifacino JS. 1999. Mu1B, a novel adaptor medium chain expressed in polarized epithelial cells. FEBS Lett 449: 215-220.

Oshio K, Watanabe H, Song Y, Verkman AS, Manley GT. 2005. Reduced cerebrospinal fluid production and intracranial pressure in mice lacking choroid plexus water channel aquaporin-1. FASEB J 19: 76-78.

Overeem AW, Bryant DM, van ISC. 2015. Mechanisms of apical-basal axis orientation and epithelial lumen positioning. Trends Cell Biol 25: 476-485.

Owen DJ, Evans PR. 1998. A structural explanation for the recognition of tyrosine-based endocytotic signals. Science 282: 1327-1332.

Padilla-Benavides T, Roldan ML, Larre I, Flores-Benitez D, Villegas-Sepulveda N, Contreras RG, Cereijido M, Shoshani L. 2010. The polarized distribution of $\mathrm{Na}^{+}, \mathrm{K}^{+}$ATPase: Role of the interaction between $\beta$ subunits. Mol Biol Cell 21: 2217-2225.

Palmer LG, Andersen OS. 2008. The two-membrane model of epithelial transport: Koefoed-Johnsen and Ussing (1958). J Gen Physiol 132: 607-612.

Parsons DS, Wingate DL. 1961. The effect of osmotic gradients on fluid transfer across rat intestine in vitro. Biochim Biophys Acta 46: 170-183.

Pearce D, Soundararajan R, Trimpert C, Kashlan OB, Deen PM, Kohan DE. 2015. Collecting duct principal cell transport processes and their regulation. Clin J Am Soc Nephrol 10: 135-146.

Pena-Munzenmayer G, Catalan M, Cornejo I, Figueroa CD, Melvin JE, Niemeyer MI, Cid LP, Sepulveda FV. 2005. Basolateral localization of native ClC-2 chloride channels in absorptive intestinal epithelial cells and basolateral sorting encoded by a CBS-2 domain di-leucine motif. $J$ Cell Sci 118: 4243-4252.

Philp NJ, Yoon H, Grollman EF. 1998. Monocarboxylate transporter MCT1 is located in the apical membrane and MCT3 in the basal membrane of rat RPE. Am J Physiol 274: R1824-1828.

Puertollano R, Martin-Belmonte F, Millan J, de Marco MC, Albar JP, Kremer L, Alonso MA. 1999. The MAL proteolipid is necessary for normal apical transport and accurate sorting of the influenza virus hemagglutinin in Madin-Darby canine kidney cells. J Cell Biol 145: 141151. 
Fluid Transport across Organ-Blood Barriers

Rafii S, Butler JM, Ding BS. 2016. Angiocrine functions of organ-specific endothelial cells. Nature 529: 316-325.

Rahner C, Fukuhara M, Peng S, Koijima S, Rizzolo LJ. 2004. The apical and basal environments of the retinal pigment epithelium regulate the maturation of tight junctions during development. J Cell Sci 117: 3307-3318.

Reczek D, Berryman M, Bretscher A. 1997. Identification of EBP50: A PDZ-containing phosphoprotein that associates with members of the ezrin-radixin-moesin family. $J$ Cell Biol 139: 169-179.

Reich V, Mostov K, Aroeti B. 1996. The basolateral sorting signal of the polymeric immunoglobulin receptor contains two functional domains. J Cell Sci 109: 2133-2139.

Reid EW. 1902. Intestinal absorption of solutions. J Physiol 28: $241-256$.

Rodman JS, Mooseker M, Farquhar MG. 1986. Cytoskeletal proteins of the rat kidney proximal tubule brush border. Eur J Cell Biol 42: 319-327.

Rodriguez ML, Brignoni M, Salas PJ. 1994. A specifically apical sub-membrane intermediate filament cytoskeleton in non-brush-border epithelial cells. J Cell Sci 107: 3145-3151.

Rodriguez-Boulan E, Macara IG. 2014. Organization and execution of the epithelial polarity programme. Nat Rev Mol Cell Biol 15: 225-242.

Rodriguez-Boulan E, Musch A. 2005. Protein sorting in the Golgi complex: Shifting paradigms. Biochim Biophys Acta 1744: 455-464.

Rodriguez-Boulan E, Pendergast M. 1980. Polarized distribution of viral envelope proteins in the plasma membrane of infected epithelial cells. Cell 20: $45-54$.

Rodriguez-Boulan E, Sabatini DD. 1978. Asymmetric budding of viruses in epithelial monolayers: A model system for study of epithelial polarity. Proc Natl Acad Sci 75: 5071-5075.

Rodriguez-Boulan E, Kreitzer G, Musch A. 2005. Organization of vesicular trafficking in epithelia. Nat Rev Mol Cell Biol 6: 233-247.

Rodriguez-Boulan E, Perez-Bay A, Schreiner R, Gravotta D. 2013. Response: The "tail" of the twin adaptors. Dev Cell 27: $247-248$.

Roignot J, Peng X, Mostov K. 2013. Polarity in mammalian epithelial morphogenesis. Cold Spring Harb Perspect Biol 5: $\mathrm{a} 013789$.

Sabolic I, Valenti G, Verbavatz JM, Van Hoek AN, Verkman AS, Ausiello DA, Brown D. 1992. Localization of the CHIP28 water channel in rat kidney. Am J Physiol 263: C1225-1233.

Saito Y, Wright EM. 1983. Bicarbonate transport across the frog choroid plexus and its control by cyclic nucleotides. $J$ Physiol 336: 635-648.

Sakaguchi TF, Sadler KC, Crosnier C, Stainier DY. 2008. Endothelial signals modulate hepatocyte apicobasal polarization in zebrafish. Curr Biol 18: 1565-1571.

Salas PJ, Rodriguez ML, Viciana AL, Vega-Salas DE, Hauri HP. 1997. The apical submembrane cytoskeleton participates in the organization of the apical pole in epithelial cells. J Cell Biol 137: 359-375.

Saotome I, Curto M, McClatchey AI. 2004. Ezrin is essential for epithelial organization and villus morphogenesis in the developing intestine. Dev Cell 6: 855-864.
Savidge TC, Newman P, Pothoulakis C, Ruhl A, Neunlist M, Bourreille A, Hurst R, Sofroniew MV. 2007. Enteric glia regulate intestinal barrier function and inflammation via release of S-nitrosoglutathione. Gastroenterology 132: 1344-1358.

Schafer JA, Patlak CS, Andreoli TE. 1977. Fluid absorption and active and passive ion flows in the rabbit superficial pars recta. Am J Physiol 233: F154-167.

Schnermann J, Chou CL, Ma T, Traynor T, Knepper MA, Verkman AS. 1998. Defective proximal tubular fluid reabsorption in transgenic aquaporin-1 null mice. Proc Natl Acad Sci 95: 9660-9664.

Schreiner R, Frindt G, Diaz F, Carvajal-Gonzalez JM, Perez Bay AE, Palmer LG, Marshansky V, Brown D, Philp NJ Rodriguez-Boulan E. 2010. The absence of a clathrin adapter confers unique polarity essential to proximal tubule function. Kidney Int 78: 382-388.

Scott RP, Quaggin SE. 2015. Review series: The cell biology of renal filtration. J Cell Biol 209: 199-210.

Shillingford JM, Miyoshi K, Flagella M, Shull GE, Hennighausen L. 2002. Mouse mammary epithelial cells express the $\mathrm{Na}-\mathrm{K}-\mathrm{Cl}$ cotransporter, NKCC1: Characterization, localization, and involvement in ductal development and morphogenesis. Mol Endocrinol 16: 13091321.

Short DB, Trotter KW, Reczek D, Kreda SM, Bretscher A, Boucher RC, Stutts MJ, Milgram SL. 1998. An apical PDZ protein anchors the cystic fibrosis transmembrane conductance regulator to the cytoskeleton. J Biol Chem 273: 19797-19801.

Simmen T, Honing S, Icking A, Tikkanen R, Hunziker W. 2002. AP-4 binds basolateral signals and participates in basolateral sorting in epithelial MDCK cells. Nat Cell Biol 4: 154-159.

Simons K, van Meer G. 1988. Lipid sorting in epithelial cells. Biochemistry 27: 6197-6202.

Siu MK, Cheng CY. 2008. Extracellular matrix and its role in spermatogenesis. Adv Exp Med Biol 636: 74-91.

Skibbens JE, Roth MG, Matlin KS. 1989. Differential extractability of influenza virus hemagglutinin during in tracellular transport in polarized epithelial cells and nonpolar fibroblasts. J Cell Biol 108: 821-832.

Sorkio A, Hongisto H, Kaarniranta K, Uusitalo H, JuutiUusitalo K, Skottman H. 2014. Structure and barrier properties of human embryonic stem cell-derived retinal pigment epithelial cells are affected by extracellular matrix protein coating. Tissue Eng Part A 20: 622-634.

Spring KR. 1998. Routes and mechanism of fluid transport by epithelia. Annu Rev Physiol 60: 105-119.

Stirling CE. 1972. Radioautographic localization of sodium pump sites in rabbit intestine. J Cell Biol 53: 704-714.

Strauss O. 2005. The retinal pigment epithelium in visual function. Phys Rev 85: 845-881.

Sun R, Peng S, Chen X, Zhang H, Rizzolo LJ. 2008. Diffusible retinal secretions regulate the expression of tight junctions and other diverse functions of the retinal pigment epithelium. Mol Vis 14: 2237-2262.

Sung CH, Tai AW. 2000. Rhodopsin trafficking and its role in retinal dystrophies. Int Rev Cytol 195: 215-267. 


\section{P.S. Caceres et al.}

Sweeney MD, Ayyadurai S, Zlokovic BV. 2016. Pericytes of the neurovascular unit: Key functions and signaling pathways. Nat Neurosci 19: 771-783.

Takeuchi K, Sato N, Kasahara H, Funayama N, Nagafuchi A, Yonemura S, Tsukita S, Tsukita S. 1994. Perturbation of cell adhesion and microvilli formation by antisense oligonucleotides to ERM family members. J Cell Biol 125: 1371-1384.

Tanos BE, Perez Bay AE, Salvarezza S, Vivanco I, Mellinghoff I, Osman M, Sacks DB, Rodriguez-Boulan E. 2015. IQGAP1 controls tight junction formation through differential regulation of claudin recruitment. J Cell Sci 128: 853-862.

Thiemann A, Grunder S, Pusch M, Jentsch TJ. 1992. A chloride channel widely expressed in epithelial and non-epithelial cells. Nature 356: 57-60.

Thomas DC, Brewer CB, Roth MG. 1993. Vesicular stomatitis virus glycoprotein contains a dominant cytoplasmic basolateral sorting signal critically dependent upon a tyrosine. J Biol Chem 268: 3313-3320.

Tisher CC, Kokko JP. 1974. Relationship between peritubular oncotic pressure gradients and morphology in isolated proximal tubules. Kidney Int 6: 146-156.

Tormey JM, Diamond JM. 1967. The ultrastructural route of fluid transport in rabbit gall bladder. J Gen Physiol 50: 2031-2060.

Turner JR. 2000. Show me the pathway! Regulation of paracellular permeability by $\mathrm{Na}^{+}$-glucose cotransport. $A d v$ Drug Deliv Rev 41: 265-281.

Utriainen A, Sormunen R, Kettunen M, Carvalhaes LS, Sajanti E, Eklund L, Kauppinen R, Kitten GT, Pihlajaniemi T. 2004. Structurally altered basement membranes and hydrocephalus in a type XVIII collagen deficient mouse line. Hum Mol Genet 13: 2089-2099.

Vagin O, Turdikulova S, Sachs G. 2005. Recombinant addition of $\mathrm{N}$-glycosylation sites to the basolateral $\mathrm{Na}, \mathrm{K}-$ ATPase $\beta 1$ subunit results in its clustering in caveolae and apical sorting in HGT-1 cells. J Biol Chem 280: 43159-43167.

Vandenbroucke RE, Dejonckheere E, Van Lint P, Demeestere D, Van Wonterghem E, Vanlaere I, Puimege L, Van Hauwermeiren F, De Rycke R, McGuire C, et al. 2012. Matrix metalloprotease 8-dependent extracellular matrix cleavage at the blood-CSF barrier contributes to lethality during systemic inflammatory diseases. J Neurosci 32: $9805-$ 9816.

Vibat CR, Holland MJ, Kang JJ, Putney LK, O’Donnell ME. 2001. Quantitation of $\mathrm{Na}^{+}-\mathrm{K}^{+}-2 \mathrm{Cl}^{-}$cotransport splice variants in human tissues using kinetic polymerase chain reaction. Anal Biochem 298: 218-230.

Watanabe T, Wang S, Noritake J, Sato K, Fukata M, Takefuji M, Nakagawa M, Izumi N, Akiyama T, Kaibuchi K. 2004. Interaction with IQGAP1 links APC to Rac1, Cdc42, and actin filaments during cell polarization and migration. Dev Cell 7: 871-883.

Wehrle-Haller B, Imhof BA. 2001. Stem cell factor presentation to c-Kit. Identification of a basolateral targeting domain. J Biol Chem 276: 12667-12674.

Weinstein AM. 1984. Transport by epithelia with compliant lateral intercellular spaces: Asymmetric oncotic effects across the rat proximal tubule. Am J Physiol 247: F848F862.
Weinstein AM. 2013. Sodium and chloride transport: Proximal nephron. In Seldin and Giebisch's the kidney (ed. Taal MW, Chertow GM, Marsden PA, Skorecki K, Yu ASL, Brenner BM), pp. 1081-1141. Elsevier, Philadelphia.

Weinstein AM, Stephenson JL. 1981. Models of coupled salt and water transport across leaky epithelia. J Membr Biol 60: $1-20$.

Weisz OA, Rodriguez-Boulan E. 2009. Apical trafficking in epithelial cells: Signals, clusters and motors. J Cell Sci 122 4253-4266.

Whitlock RT, Wheeler HO. 1964. Coupled transport of solute and water across rabbit gallbladder epithelium. J Clin Invest 43: 2249-2265.

Williams AW. 1963. Electron microscopic changes associated with water absorption in the jejunum. Gut 4: 1-7.

Wilson RW, Wareing M, Green R. 1997. The role of active transport in potassium reabsorption in the proximal convoluted tubule of the anaesthetized rat. J Physiol 500: $155-164$.

Wilson RW, Wareing M, Kibble J, Green R. 1998. Potassium permeability in the absence of fluid reabsorption in proximal tubule of the anesthetized rat. Am J Physiol 274: F1109-F1112.

Windhager EE, Whittembury G, Oken DE, Schatzmann HJ, Solomon AK. 1959. Single proximal tubules of the Necturus kidney. III: Dependence of $\mathrm{H}_{2} \mathrm{O}$ movement on $\mathrm{NaCl}$ concentration. Am J Physiol 197: 313-318.

Wolburg H, Wolburg-Buchholz K, Liebner S, Engelhardt B. 2001. Claudin-1, claudin-2 and claudin-11 are present in tight junctions of choroid plexus epithelium of the mouse. Neurosci Lett 307: 77-80.

Worzfeld T, Schwaninger M. 2016. Apicobasal polarity of brain endothelial cells. J Cereb Blood Flow Metab 36: $340-362$.

Wright EM. 1978. Transport processes in the formation of the cerebrospinal fluid. Rev Physiol Biochem Pharmacol 83: 3-34.

Yamada S, Pokutta S, Drees F, Weis WI, Nelson WJ. 2005. Deconstructing the cadherin-catenin-actin complex. Cell 123: 889-901.

Yamamoto H, Ehling M, Kato K, Kanai K, van Lessen M, Frye $M$, Zeuschner $D$, Nakayama $M$, Vestweber $D$, Adams RH. 2015. Integrin $\beta 1$ controls VE-cadherin localization and blood vessel stability. Nat Commun 6: 6429 .

Yang X, Scott HA, Monickaraj F, Xu J, Ardekani S, Nitta CF Cabrera A, McGuire PG, Mohideen U, Das A, et al. 2016. Basement membrane stiffening promotes retinal endothelial activation associated with diabetes. FASEB J 30: 601-611.

Yao Y, Chen ZL, Norris EH, Strickland S. 2014. Astrocytic laminin regulates pericyte differentiation and maintains blood brain barrier integrity. Nat Commun 5: 3413 .

Zeuthen T. 1991a. Secondary active transport of water across ventricular cell membrane of choroid plexus epithelium of Necturus maculosus. J Physiol 444: 153-173.

Zeuthen T. 1991b. Water permeability of ventricular cell membrane in choroid plexus epithelium from Necturus maculosus. J Physiol 444: 133-151. 
Fluid Transport across Organ-Blood Barriers

Zeuthen T. 2002. General models for water transport across leaky epithelia. Int Rev Cytol 215: 285-317.

Zeuthen T, Macaulay N. 2012. Cotransport of water by $\mathrm{Na}^{+}-$ $\mathrm{K}^{+}-2 \mathrm{Cl}^{-}$cotransporters expressed in Xenopus oocytes: NKCC1 versus NKCC2. J Physiol 590: 1139-1154.

Zeuthen T, Stein WD. 1994. Cotransport of salt and water in membrane proteins: Membrane proteins as osmotic engines. J Membrane Biol 137: 179-195.
Zhang R, Skach W, Hasegawa H, van Hoek AN, Verkman AS. 1993. Cloning, functional analysis and cell localization of a kidney proximal tubule water transporter homologous to CHIP28. J Cell Biol 120: 359369.

Zhao Z, Nelson AR, Betsholtz C, Zlokovic BV. 2015. Establishment and dysfunction of the blood-brain barrier. Cell 163: 1064-1078. 


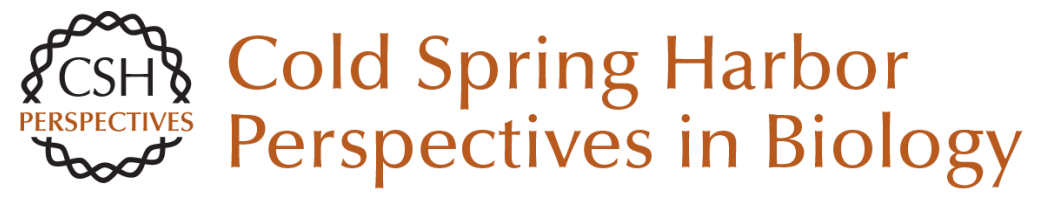

\section{Directional Fluid Transport across Organ-Blood Barriers: Physiology and Cell Biology}

Paulo S. Caceres, Ignacio Benedicto, Guillermo L. Lehmann and Enrique J. Rodriguez-Boulan

Cold Spring Harb Perspect Biol 2017; doi: 10.1101/cshperspect.a027847 originally published online December 21, 2016

\section{Subject Collection Cell Polarity}

Regulation of Cell Polarity by Exocyst-Mediated

Trafficking Noemi Polgar and Ben Fogelgren

Phosphoinositides and Membrane Targeting in Cell Polarity Gerald R. Hammond and Yang Hong

Trafficking lon Transporters to the Apical Membrane of Polarized Intestinal Enterocytes Amy Christine Engevik and James R. Goldenring

Signaling Networks in Epithelial Tube Formation Ilenia Bernascone, Mariam Hachimi and Fernando Martin-Belmonte

Making Heads or Tails of It: Cell-Cell Adhesion in Cellular and Supracellular Polarity in Collective Migration Jan-Hendrik Venhuizen and Mirjam M. Zegers

Laminins in Epithelial Cell Polarization: Old Questions in Search of New Answers Karl S. Matlin, Satu-Marja Myllymäki and Aki Manninen

Epithelial Morphogenesis during Liver Development

Naoki Tanimizu and Toshihiro Mitaka
The Crumbs3 Polarity Protein

Ben Margolis

Microtubule Motors in Establishment of Epithelial Cell Polarity Geri Kreitzer and Monn Monn Myat

Role of Polarity Proteins in the Generation and

Organization of Apical Surface Protrusions Gerard Apodaca

Polarized Exocytosis Jingwen Zeng, Shanshan Feng, Bin Wu, et al.

Regulation of Transporters and Channels by Membrane-Trafficking Complexes in Epithelial Cells

Curtis T. Okamoto

Membrane Transport across Polarized Epithelia Maria Daniela Garcia-Castillo, Daniel J.-F. Chinnapen and Wayne I. Lencer

Mechanisms of Cell Polarity-Controlled Epithelial Homeostasis and Immunity in the Intestine Leon J. Klunder, Klaas Nico Faber, Gerard Dijkstra, et al.

For additional articles in this collection, see http://cshperspectives.cshlp.org/cgi/collection/

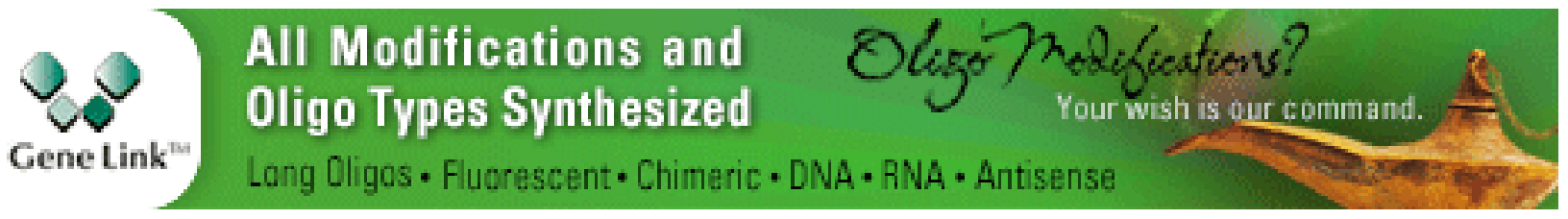


Targeting the Mucosal Barrier: How Pathogens Modulate the Cellular Polarity Network Travis R. Ruch and Joanne N. Engel

\section{The Biology of Ciliary Dynamics}

Kuo-Shun Hsu, Jen-Zen Chuang and Ching-Hwa Sung

For additional articles in this collection, see http://cshperspectives.cshlp.org/cgi/collection/

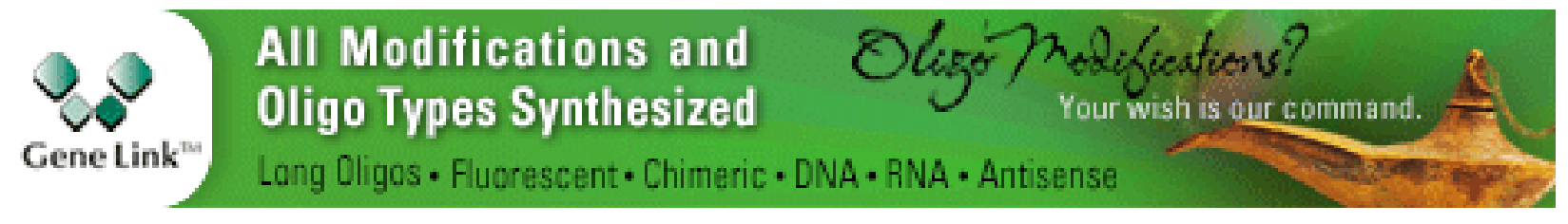

Copyright @ 2017 Cold Spring Harbor Laboratory Press; all rights reserved 